\title{
露出柱脚付鋼構造物の地震応答時における柱脚部存在応力と変形挙動
}

\author{
- 4 層平面ラーメン架構の時刻歴応答解析結果に基づいて - \\ DEFORMATION BEHAVIOR \& WORKING STRESS OF COLUMN-BASE FOR \\ STEEL STRUCTURE WITH EXPOSED COLUMN-BASE ON GROUND MOTION
}

- Time history response analysis for 4-story 2-dimension moment resist frame -

\author{
山西央 朗*1
}

\section{Teruaki YAMANISHI}

\begin{abstract}
Resistance characteristics of exposed column-base varied column axial force, and it many used in low-rise and middle-rise steel structures. Moreover, it is difficult to estimate of exposed column-base behaviour subjected to working stress of generally structure on ground motion.

The author discussed behaviour of exposed column-base and column-base around member on ground motion, that uses seismic response analysis results obtain from low-rise steel structure with model that can reproduce the column-base behaviour. In this paper, elucidate and estimate for exposed column-base mechanism and effective working stress, frame response.
\end{abstract}

Keywords : exposed column-base, collapse mechanism, column-base working stress, column-base rotational rigidity, base-plate rotation

露出柱脚, 崩壊機構, 柱脚存在応力, 柱脚回転剛性, ベースプレート回転角

\section{1 序論}

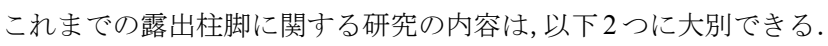
・部材実験等の結果から, 接合部挙動の理解を深める研究例えば1-8)

・露出柱脚をスリップ型履歴形状を持つ弾塑性回転バネ（以後，回転 バネと記す）で再現した構造物の時刻歴応答解析結果から, 露出 柱脚と架構との相互関係を紐解こうとする研究例えば1, 9 10)

前者は, 露出柱脚の塑性変形能力を向上させることを目的に, ア ンカーボルト抜出しを防止するための埋め込み深さ1)，アンカーボ ルト自身の伸び能力に関する知見 ${ }^{2)}$, ベースプレートと基礎コンク リートとの支圧状態を詳細に表現するための評価法 ${ }^{3-8)}$ などの導出に 注力しており, 今日定められている露出柱脚細部の構造規定を築く 礎となっている. 後者は, 構造規模や露出柱脚部の履歴形状を变数 とした結果を比較して, 露出柱脚の履歴形状が構造物応答に与える 影響は少なく, 更に, 柱脚の特性を表現する上で最大耐力を表現す ることが重要である等, 全体応答の最大值を議論する時の柱脚の取 り扱いやその影響に関する知見が得られている ${ }^{1,9,10)}$. また，回転バ ネの曲げ耐力・回転剛性を变数とした応答解析結果から, 柱と柱脚 の耐力比毎に確保すべきべースプレート回転角の值も示している ${ }^{11)}$.

しかしながら, これら研究では柱脚の抵抗特性または構造物全体 の応答を効率よく議論するため, 実際の挙動・境界条件を一部簡略 化して実施している，具体的には，部材実験では柱曲げモーメント 反曲点高さを固定, 柱軸力履歴を単純化し, 更に, 時刻歴応答解析
では回転バネを用いることで柱軸力による付加曲げ抵抗等が精確に は再現されない.このため, 露出柱脚における存在応力が精確には 追跡されておらず, 部材実験等で蓄積した知見を活用した露出柱脚 の合理的設計を未だ追跡できない，また，構造物全体の時刻歴応答 を考える場合, 弾性域における柱脚挙動が周辺架構に与える影響等 を無視し得るか等, 露出柱脚の扱いに曖昧な部分を残している.

一方, いくつかの研究では, 露出柱脚挙動を再現するモデルを用 いた時刻歷応答解析 ${ }^{12 \sim 15}$ が実施しされているが, 全体応答の議論や, 全体応答を得るための回転バネの取り扱いに着目しているのみであ

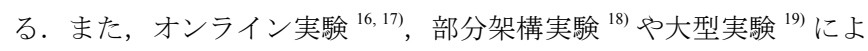
る研究も実施されており, 構造規模や露出柱脚耐力を変数とするこ とで露出柱脚の合理的な設計に必要な諸量の一端は示されているが, 一般的な条件下における理解や各数值が得られた理論的背景の追跡 が十分に行えているとは言えない.

このような背景の下, 本研究では, 柱軸力による付加曲げ抵抗を 表現した露出柱脚の構造モデルを 4 層構造物 ${ }^{20)}$ の平面架構に設置し, 構造物内における露出柱脚部の存在応力と変形挙動を明らかにする ことを目的とする. 更に, 架構の崩壊機構や, 力学モデルを用いて 露出柱脚に作用寸る存在応力や, 一般に認識の統一されていない回 転剛性の取り扱いに関する理論的な追跡を行い, 部材実験結果と回 転バネを用いた時刻歴応答解析結果とを紐付ける知見を追跡する.

•1 広島工業大学工学部建築工学科 准教授 ·博士 (工学) Assoc. Prof., Faculty of Eng., Hiroshima Institute of Technology, Dr.Eng. 


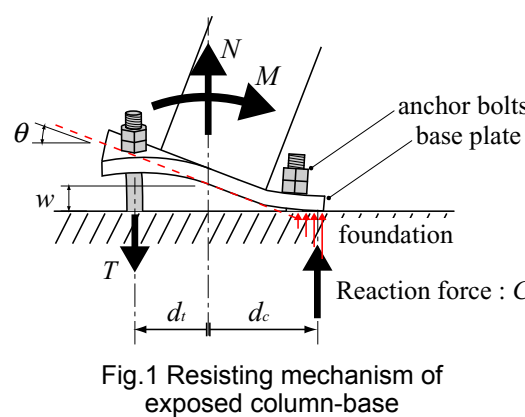
exposed column-base

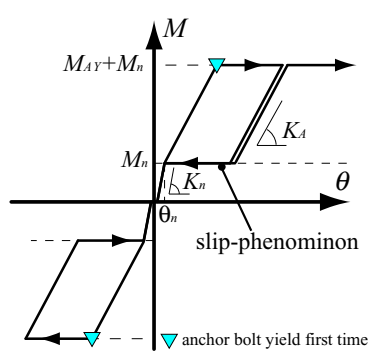

Fig.2 Double flag type restoring force characteristics

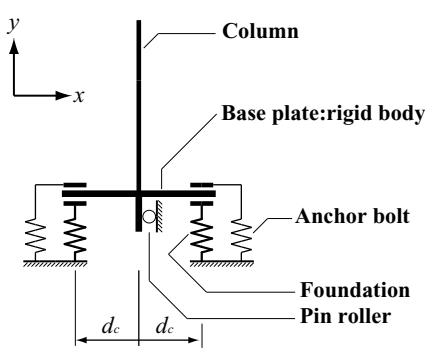

Fig.3 Model of exposed column-base for ordinary type

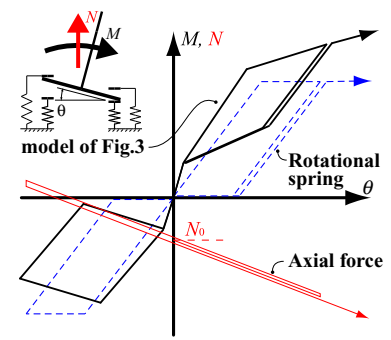

Fig.4 Hysteresis of variable axial force with exposed column-base

\section{2. 露出柱脚挙動を再現するためのモデル}

地震時に柱脚の曲げ応力が卓越すると, 露出柱脚は図 1 に示寸抵 抗機構を示寸. また, 柱軸力が付加曲げ抵抗 $M_{n}$ として現れ, 復元力 特性は図 2 のダブルフラッグ型となる. 柱脚の保有する耐力に対し て柱の耐力が上回る場合は図 2 の履歴形状が現われ，下回る場合は 柱脚が弾性回転しながら柱の履歴形状である紡鍾型が現われる.

\section{1 モデルの構成}

図 1 の露出柱脚の挙動を再現するため, ビーム要素, バネ要素を 用いて図 3 に示すモデルを構築する．柱下端部に剛と見なせるビー ム要素を設けてこれをべースプレートとし，その先端に基礎との接 触離間, アンカーボルトのナットとの接触離間を再現したバネを設 置する。また, 柱直下に水平変位を拘束するピンローラーを設け, 摩擦力による柱脚せん断力支持状態を表す.

各バネは, アンカーボルトを弾性剛性と降伏耐力を有する完全弾 塑性型のモデル，基礎を弾性剛性のみを有する線形（弾性）のモデ ルで表現する。このため，基礎コンクリートが圧縮破壊や割裂破壊 が生じるような領域は適用範囲外 ${ }^{23)}$ となる。本論文では, 基礎コン クリートの圧縮耐力（コンクリート圧縮強度 $=24 \mathrm{~N} / \mathrm{mm}^{2}$ として算出） に対して, 柱軸力変動を加味した最も存在応力の大きい状態でも圧 縮耐力の $20 \%$ 程度となり圧縮破壊を生じない領域であることを確認 している.

このモデルであれば, 柱軸力による付加曲げ抵抗が現われ, 例えば, 柱軸力が圧縮一定の時に図 2 のダブルフラッグ型を示す. 更に, 図 4 に示すように，変動する柱軸力（赤線）に対して, 露出柱脚と同様 に逐次柱軸力による付加曲げ抵抗が変化する。同図中には，回転バ ネの履歴（青色破線）も示しているが，回転バネは軸力に対して独 立しているので, 露出柱脚の挙動を再現しない. 尚, 同モデルにつ いては既報の論文 ${ }^{21,22)}$ にて再現性の確認を終えている.

\section{2 露出柱脚挙動再現モデルの各種バネ特性算定手法}

図 1 に示寸露出柱脚の抵抗機構の柱断面図心位置に着目した曲げ モーメントの釣合いを利用して, 柱断面図心から接触反力（ベース プレートが基礎を圧縮する力) の合力 $C$ までの距離 (圧縮合力点位置) $d_{c}$ を定義すると, 以下の式となる.

$$
d_{c}=\frac{M-\sum T_{i} \cdot d_{t i}}{C}=\frac{M-\sum T_{i} \cdot d_{t i}}{N-\sum T_{i}}
$$

また，本論のモデルでは $d_{c}$ の位置にアンカーボルトを設ける．ア ンカーボルトの抵抗による曲げ耐力を再現するため, 以下の式を用 いて, アンカーボルトの降伏応力度を調整する. 尚、モデルのため に調整した諸量にはトップバーを振る。

$$
\overline{\sigma_{Y i}}=\frac{M_{A Y i}}{n_{i} \cdot A_{A i} \cdot 2 \cdot d_{c}}
$$

ここに, $\Sigma T_{i} \cdot d_{t i}: i$ 列の柱断面図心周りのアンカーボルト軸力に基 因した曲げモーメント総和, $\Sigma T_{i}: i$ 列のアンカーボルト軸力の総和, $M_{A Y i}: i$ 列のアンカーボルト降伏軸力による柱脚曲げ耐力, $n_{i}: i$ 列の アンカーボルト本数, $A_{A i}: i$ 列のアンカーボルト断面積, $\overline{\sigma_{Y i}}: i$ 列の アンカーボルト降伏応力度である.

次いで，基礎からの抵抗を再現したバネ（基礎バネ）と，アンカー ボルトの抵抗を再現したバネは, 図 2 に示寸露出柱脚の $M-\theta$ 関係上 で得られる諸量を用い, 以下の式によりバネ特性を定める.

$$
\begin{aligned}
& \overline{K_{F}}=\frac{\overline{A_{F}} \cdot E}{\overline{L_{F}}}=\frac{K_{n}}{2 \cdot d_{c}^{2}}=\frac{N}{\theta_{n} \cdot 2 d_{c}} \\
& \overline{L_{A i}}=\frac{n_{i} \cdot A_{A i} \cdot E \cdot\left(2 d_{c}\right)^{2}}{K_{A i}}-n \cdot \frac{E \cdot A_{A i}}{\overline{K_{F}}}
\end{aligned}
$$

ここに, $\overline{K_{F}}, \overline{A_{F}}, \overline{L_{F}}$ : 基礎バネの軸剛性，断面積と長さ， $K_{n}, \theta_{n}$ : 付 加曲げ抵抗域の回転剛性と付加曲げ抵抗力到達時回転角, $N$ : 柱脚に 作用寸る柱軸力 (長期) $, \overline{L_{A i}}: i$ 列のアンカーボルトの抵抗を再現し たバネの長さ, $K_{A i}: i$ 列のアンカーボルトの弾性伸びに基因した柱脚 回転剛性である.

これらの式を用いて各バネを設定すれば， $M-\theta$ 関係上の履歴形状 はほぼ再現できる. 尚, 多数のアンカーボルト列が抵抗する場合は, 各アンカーボルト列に基因した特性を抽出して，1 列ずつバネ特性を 定めれば良い。

\section{3. 時刻歴地震応答解析概要}

解析には「任意形状立体フレームの弾塑性解析ソフト SNAP Ver.6.0」を用い，時間刻み 0.005 秒，減衰定数はレーリー型で $h=0.02$ とする．解析の対象は，文献 ${ }^{20)}$ に示されている例題建物（低層）の Y3 通りの構面（平面架構）とする. 但し，柱脚は固定端として取り 扱われており, 露出柱脚のディテールは定められていない.ここでは, 試設計の後に「汎用有限要素法解析プログラムADINA ver.9.3」によ る FEM 解析を実施し, 当該結果に基づいてモデルの諸量を決定する.

尚，柱脚降伏型となる場合は，一般的には第一層上梁の断面を大 きくして第一層保有水平耐力の低下を防ぐが，ここでは，柱脚以外 の部材は変数としていない.

\section{1 解析対象の基本情報}

図 5, 表 1 に本論文で検討対象とする構造物の概要を示す.

対象架構は 4 層ラーメン架構であり, 梁中立軸を構造階高とする フレームモデルへ置換し, 表 1 に示寸部材の断面積, 断面二次モー メント, 塑性断面係数を入力する. 尚, 各部材は断面諸量を加味し た $M-N$ 耐力相関関係， 2 次勾配を $1 / 100$ とする移動硬化則が再現され ている．また，床スラブの合成効果を表現するために梁のヤング係 数を 1.5 倍とし, 各質量は柱梁接合部に集約して配置する. 
Table 1 Member list of analysis target frame (a) Coumn (BCP-325)

\begin{tabular}{|c|c|c|c|c|c|}
\hline position-layer & section sha & apec & $(\mathrm{mm})$ & $E\left(\mathrm{~N} / \mathrm{mm}^{2}\right)$ & $\sigma_{Y}\left(\mathrm{~N} / \mathrm{mm}^{2}\right)$ \\
\hline $\mathrm{C} 2-4$ & $\square-400$ & $\mathrm{x}$ & 16 & 205,000 & 357.5 \\
\hline $\mathrm{C} 2-3$ & $\square-450$ & $\mathrm{x}$ & 19 & 205,000 & 357.5 \\
\hline $\mathrm{C} 2-2$ & $\square-450$ & $\mathrm{x}$ & 19 & 205,000 & 357.5 \\
\hline C2 - 1 & $\square-500$ & $\mathrm{x}$ & 19 & 205,000 & 357.5 \\
\hline C3 - 4 & $\square-350$ & $\mathrm{x}$ & 16 & 205,000 & 357.5 \\
\hline $\mathrm{C} 3-3$ & $\square-350$ & $\mathrm{x}$ & 16 & 205,000 & 357.5 \\
\hline C3 - 2 & $\square-400$ & $\mathrm{x}$ & 19 & 205,000 & 357.5 \\
\hline C3 - 1 & $\square-400$ & $\mathrm{x}$ & 19 & 205,000 & 357.5 \\
\hline
\end{tabular}

(b) Beam (SN490B)

\begin{tabular}{llcc}
\hline position-floor & section shaped $(\mathrm{mm})$ & $E^{*}\left(\mathrm{~N} / \mathrm{mm}^{2}\right)$ & $\sigma_{Y}\left(\mathrm{~N} / \mathrm{mm}^{2}\right)$ \\
\hline \hline G2 - R & H $-550 \times 200 \times 9 \times 16$ & 307,500 & 357.5 \\
G2 - 4 & H $-550 \times 250 \times 9 \times 19$ & 307,500 & 357.5 \\
G2 -3 & H $-600 \times 250 \times 12 \times 22$ & 307,500 & 357.5 \\
G2-2 & H $-650 \times 250 \times 12 \times 22$ & 307,500 & 357.5 \\
\hline
\end{tabular}
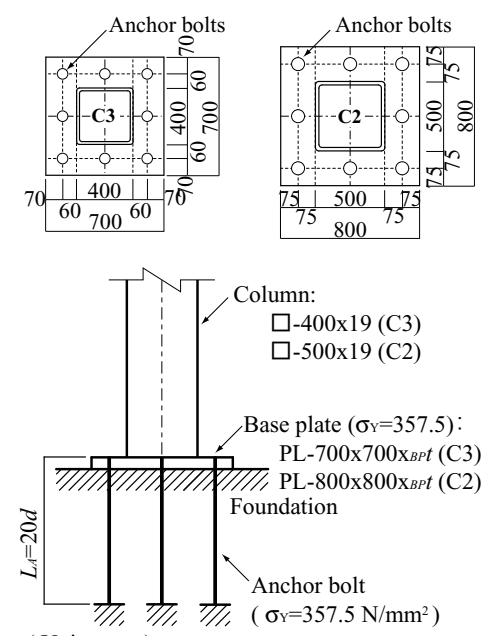

(Unit : $\mathrm{mm}$ )

(a) Ordinary shped of exposed column-base
Tabel 2 Strength ratio, each value for modeling, each strenght and stiffness for column-base

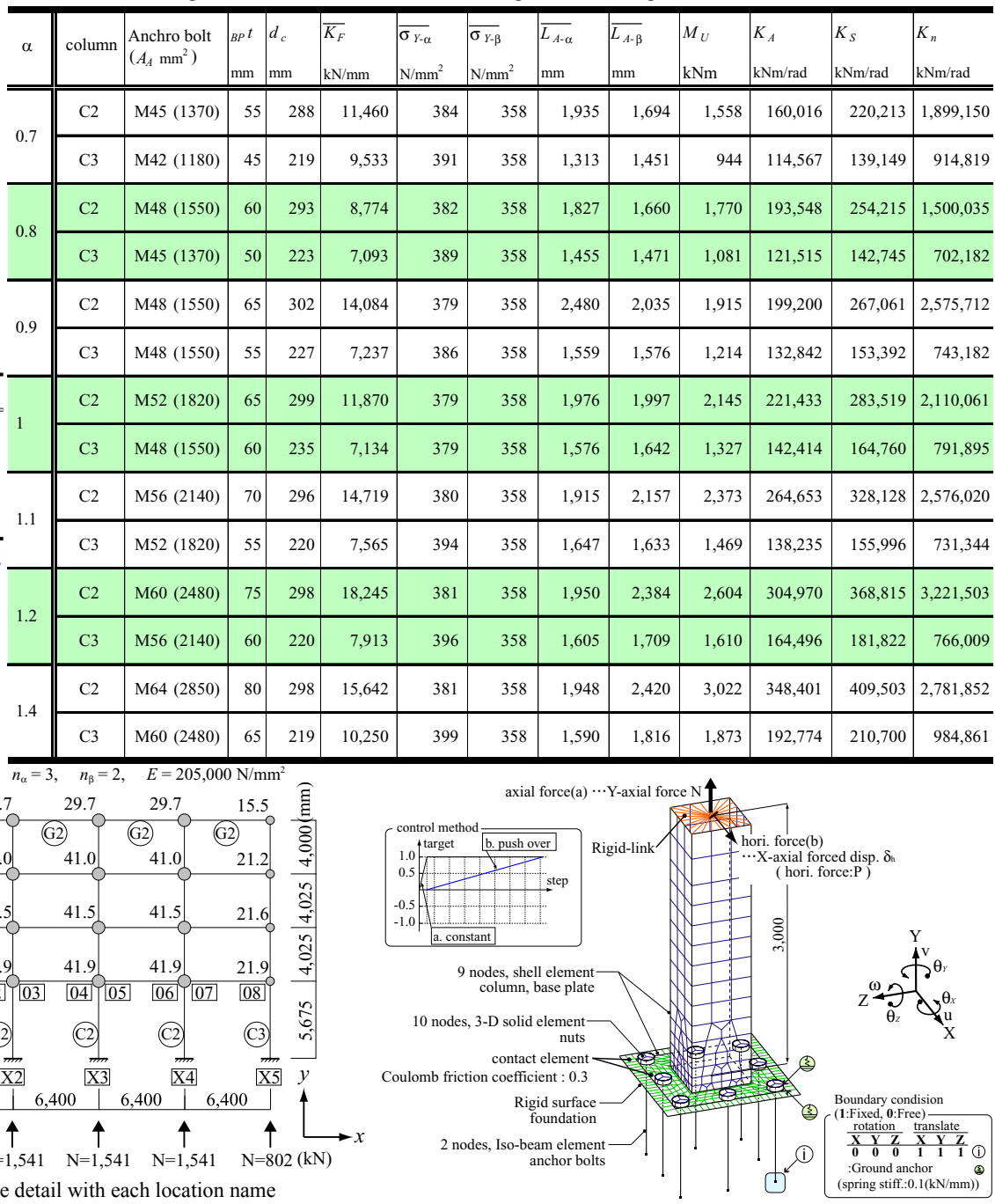

Fig. 6 Model of FEM Fig.5 Analysis target frame

\section{2 露出柱脚の試設計と構造性能決定方法}

図 5 (a) に示寸形状を露出柱脚の基本とし, アンカーボルト断面を 変数とした FEM 解析モデル (図 6 参照) を構築する. FEM 解析では アンカーボルト軸剛性は $A_{A} \cdot E / L_{A}$ で算出してコンクリートの付着等の 効果は考えていない. 柱材は鋼材のヤング係数を有する弾性体、基 礎は剛面とする。ナットとベースプレート, 基礎とベースプレート 間に接触要素を設け, アンカーボルトの曲げに対する抵抗, 柱軸力 による付加曲げを表現する. 境界条件は、アンカーボルト下端部の 全方向並進を拘束し, 柱頭部に Y 軸方向力と X 軸方向強制変位を入 力する. 尚, 本論文では, 露出柱脚それ自体の精度を追跡すること ではなく，どのように理解すべきかを追跡することを目的としてい る. FEM 解析簡単化のため基礎部には剛面を設けており, 精度の高 い解析結果とはなっていないことに留意されたい.

FEM 解析から得られた最大耐力を指標に, 各柱脚の柱に対する耐 力比 $\alpha$ を定める.

$\alpha=M_{u} /{ }_{c} M_{p c}$

ここに, $M_{u}$ : 柱脚の最大曲げ耐力, ${ }_{C} M_{P C}: M-N$ 耐力相関関係を考慮 した柱の全塑性モーメントである.

FEM 解析は, 柱材を弾性部材, 柱軸力を一定 (C2 では $-1,541 \mathrm{kN}$, C3では $-802 \mathrm{kN}$ として, 長期の柱軸力を与える) として実施し, $\alpha$ を 0.7 ,
0.8, 0.9, 1.0, 1.1, 1.2, 1.4 とするためのディテールを決定する. 更に, 2 章に示した手法により, 図 7 のモデルを構築するための諸量を得る. 表 2 に各柱脚の性能, ディテールを, 図 8 に表 2 中の $K_{S}$ の定義を, 図 9 に $\alpha$-柱脚回転剛性の分布を, それぞれ示寸. 図 8 中, $M_{Y}$ は柱 脚の降伏曲げ耐力 $\left(\alpha\right.$ 列降伏時), $M_{U}$ は柱脚の最大曲げ耐力 $(\beta$ 列降 伏時), $K_{s}$ は原点と $M_{Y}$ の 2 点を結んだ割線回転剛性である. 図 9 中, 5.3 節で提示する式から得た值も併記する. また, 図 10 に FEM 解析 と本モデルの $M-\theta$ 関係の一例を示寸が，ほぼ整合が取れている.

\section{3 解析変数}

架構は, 柱脚を 3.2 節に記した露出柱脚 $(\alpha=0.7 \sim 1.4)$, または固定 端 (Fixed) とした 8 体を用意する。

水平加速度は，記録波 3 波（El-centro NS, Hachinohe EW, Taft EW) を最大速度が $0.50 \mathrm{~m} / \mathrm{s}$ となるように加速度を基準化したものと BCJL2 を選定している. 更に, 大変形領域の挙動を明瞭に議論するため に El-centro NS と Hachinohe EW については最大速度が $0.75 \mathrm{~m} / \mathrm{s}$ とな るように加速度を基準化したものも選定し, 計 48 ケースを主な解析 変数とする. また, $\mathrm{Ai}$ 分布による静的荷重増分解析も実施する. 尚, 各解析には鉛直方向加速度として, 表 3 (a) 最下段に記した重力加速 度 $(\mathrm{G})$ を同時に入力し, 露出柱脚に構造物自重に基因した柱軸力に よる付加曲げ抵抗力も発現させる.（解析 I) 
Table 3 Acceleration list

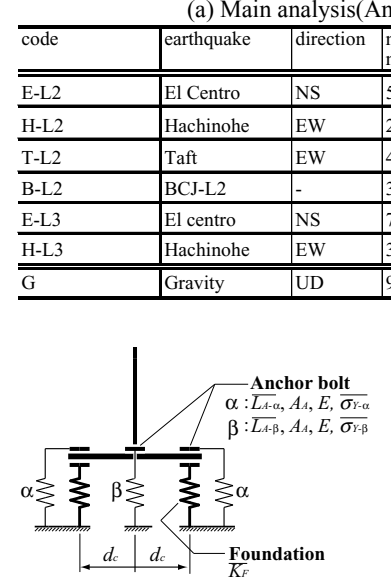

Fig.7 Each value with model
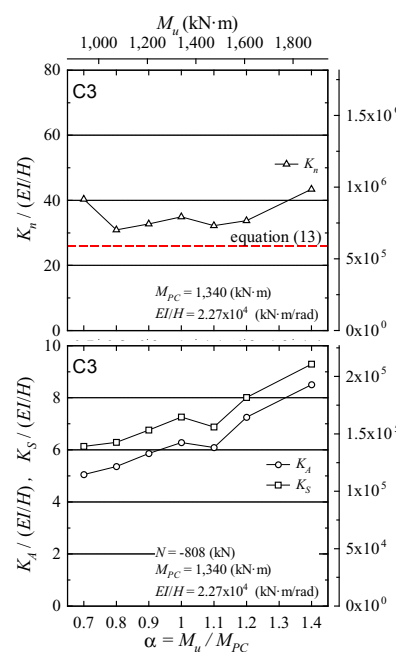

Fig.9 Rotational stiffness vs. strength ratio

ところで，建築構造物の地震時応答を議論する場合，鉛直方向の 加速度による影響は小さいとして水平加速度のみを入力するのが一 般的である. しかしながら, 露出柱脚の弾塑性挙動は柱軸力に大き く依存するため, 鉛直加速度による柱軸力の変動が露出柱脚付鋼構 造物に与える影響を吟味すべきである. そこで, 表 3 (b) に示す水平・ 鉛直地震動の組合せを入力した解析も実施する。(解析 II)

図 11 に, 上述の解析変数の表記方法例を記す. 柱脚の状態, 水平 加速度, 鉛直加速度の順に記号を組み合わせて変数を表現する.

\section{4. 露出柱脚付鋼構造物の応答解析結果による基本挙動の確認}

ここでは，5章にて露出柱脚周り挙動追跡に利用する露出柱脚付鋼 構造物の基本的な地震応答時の挙動について確認を行う.

図 12 に静的荷重増分解析時の層せん断力 $Q_{i}$ - 層間変形角 $r_{i}$ 関係の 代表值を示寸. 次に, 解析 I の結果として, 図 13 に最大層間変形角 $r_{i \max }$ の分布と地震後残留変形 $r_{R}$ （地震動による振動がほぼ終了してい る， 70 秒時点の層間変形角とする．但し，B-L2 は継続時間が 120 秒 であるので，150 秒時点の層間変形角と寸る.）の分布を, 図 14 に各 $\alpha$ に対する結果と Fixed の結果における最大層間変形角比, 図 15-18 に第一層柱下端部, 第一層上梁端部の最大塑性率 $\eta_{\text {max }}$ および累積塑 性変形倍率 $\eta_{\text {accumulation }}$ を, 図 19 に露出柱脚の正方向および負方向塑性 率 $\eta^{+}, \eta^{-}$を, 図 20 27 に代表変数の柱脚部曲げモーメント $M$ - 柱軸力 $N$ 耐力相関関係, $M$ - ベースプレート回転角 $\theta$ 関係, $N-\theta$ 関係, $M$ -

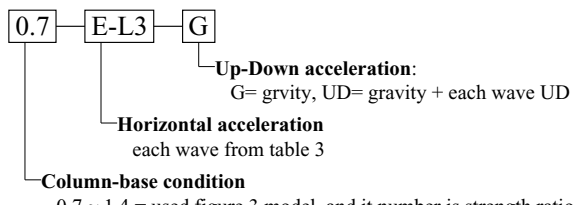

$0.7 \sim 1.4=$ used figure 3 model, and it number is strength ratio Fixed $=$ column-base fixed end

Fig.11 Code of analysis parameter

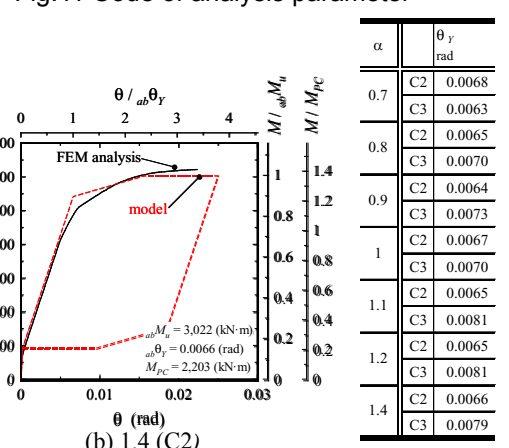

(b) $1.4(\mathrm{Cad})$

Fig.10 Exposed column-base restoring force characteristics for model with FEM

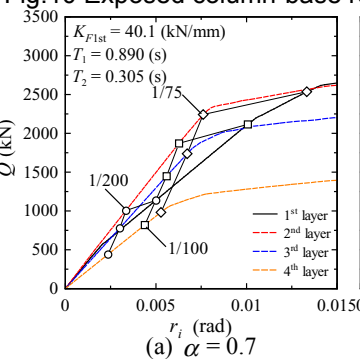

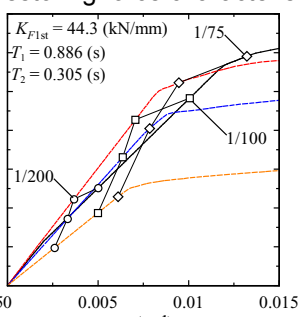

(b) $\alpha=1.4$

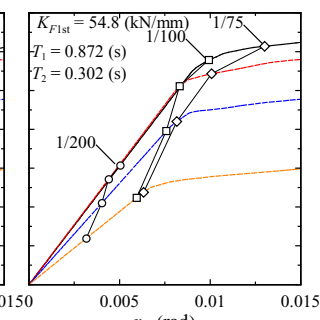

$r_{i}$ (rad)
(c) Fixed

Fig.12 Story shear force vs. story drift angle for Static load incremental analysis

柱下端変形 $\phi_{c}$ 関係, 第一層上梁端曲げモーメント $m$ - 梁端変形 $\phi_{b}$ 関係, 第一層の層せん断力 $Q_{1}$ - 層間変形角 $r_{1}$ 関係, 第一層各柱の $Q_{C}-r_{1}$ 関 係, 任意時刻の架構の変形状態（地盤からの相対変位）を示す. また, 図 14 には各層の平均值と標準偏差を併記する. 尚, 各グラフに示寸梁, 柱および柱脚の凡例名称は, 図 5 (b) に示寸位置と対応している.

但し, 図 22, 23, 26 については, 中柱の代表值としてX3 のみを示し, 更に図 26 については, 履歴が重複することによる見難さを回避する ため, X1，X5 の結果を 0.025(rad) 平行移動して描画している. また, 図 15 19 の各塑性率, 累積塑性変形倍率は図 21, 図 23, 図 24 に示 寸局所の応力 - 変形関係の履歷から算出している. 尚, 無次元化軸 として, 図 20 上横軸は柱脚最大耐力 $M_{U}$ (長期荷重による軸力で算定), 右縦軸はアンカーボルト降伏軸力の総和 $\Sigma T_{Y}$ で, 図 21 上横軸は柱脚 降伏回転角 $\theta_{Y}$, 右綐軸は $M_{U}$ と柱の全塑性曲げ耐力 $M_{P C}$ で, 図 25 右 縦軸は層に作用する重量 $w_{1}$ で除したせん断力係数を設けている.

\section{1 全体応答における柱と露出柱脚耐力比の影響}

図 12 より, $\alpha=0.7 \rightarrow 1.4$ という変化に対して, 第一層の層剛性 $K_{F 1 \mathrm{st}}$ は $40.1 \rightarrow 44.3(\mathrm{kN} / \mathrm{mm})$ と 1 割程度増大しているが, 1 次固有周 期 $T_{1}$ は $0.890 \rightarrow 0.886(\mathrm{~s})$ と影響が緩慢である. 次に, 図 13 より $\alpha$ が 低下寸ると共に第一層の最大層間変形角は増大している．第二層以 上においても $\alpha$ 変化の影響は現われるが，第一層の影響に比較して 緩慢である.これらは, 図 14 における第一層の平均值 1.485 1.925 倍に対して, 第二層以上 $0.794 \sim 1.128$ 倍であることからも読み取れる. $\alpha$ の変化 (第一層の保有水平耐力, 層剛性, 柱脚の履歴形状の変化) は第一層への影響が大きく, 第二層以上においても影響はあるが比 較的小さい. これを勘案し, 以後は柱脚周辺の挙動, 並びに第一層 の挙動に重点を置き議論する. 

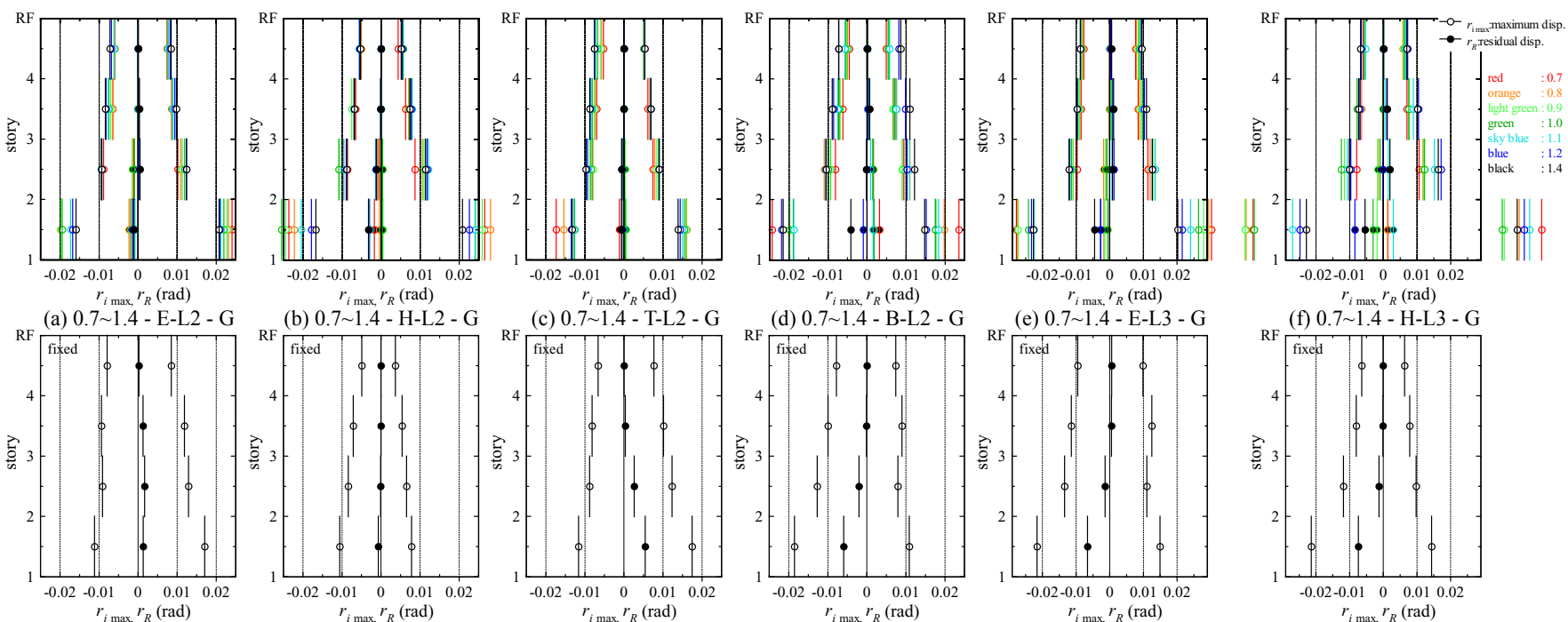

(g) Fixed - E-L2 - G

(h) Fixed - H-L2 - G

(i) Fixed - T-L2 - G

) Fixed - B-L2 -

(k) Fixed - E-L3 -

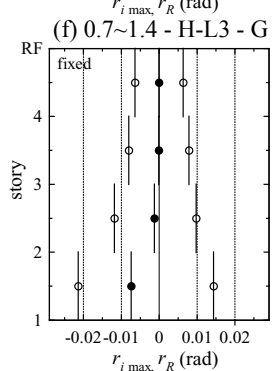

(1) Fixed - H-L3 - G
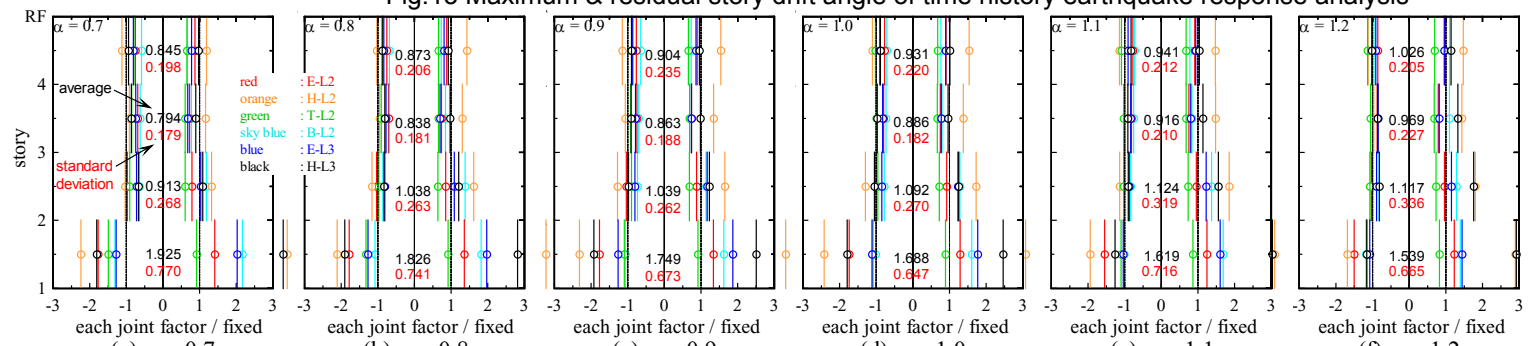

$\begin{array}{lll}\text { (b) } \alpha=0.8 & \text { (c) } \alpha=0.9 & \text { (d) } \alpha=1.0\end{array}$

each joint factor / fixe (f) $\alpha=1.2$

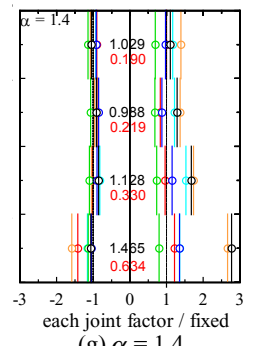
Fig.14 Ratio of each strength ratio story drift angle and fixed story drift angle
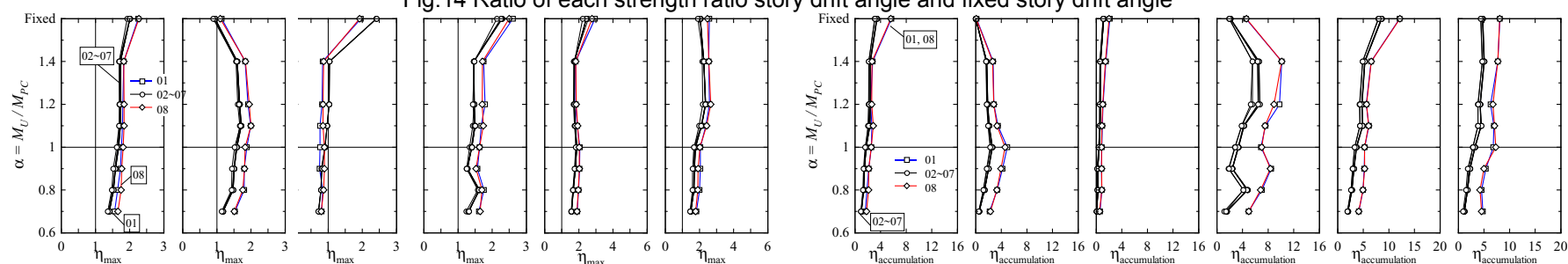

(a) E-L2 - G (b) H-L2 - G (c) T-L2 - G (d) B-L2 - G (e) E-L3-G (f) H-L3 - G Fig. 15 Plastic rate of beam

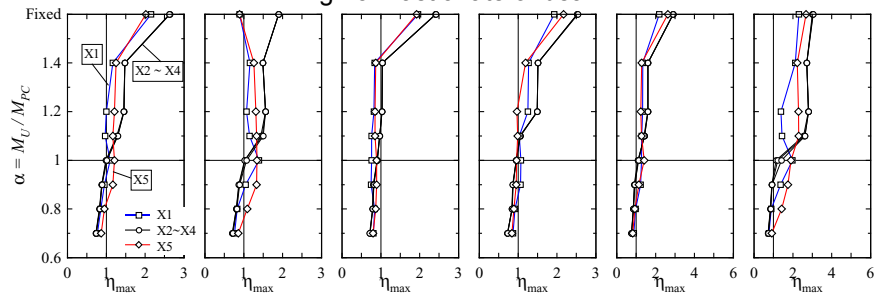

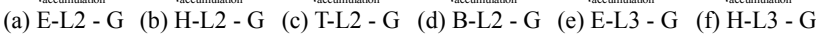

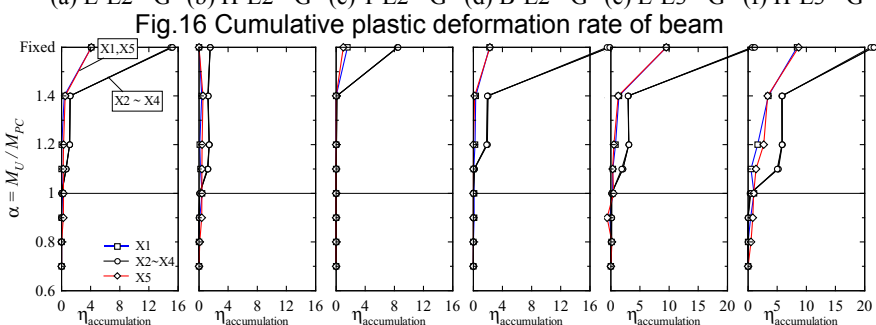

(a) E-L2 - G (b) H-L2 - G (c) T-L2 - G (d) B-L2 - G (e) E-L3 - G (f) H-L3 - G Fig.17 Plastic rate of column

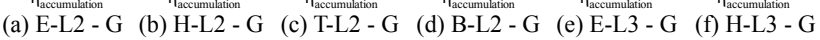
Fig.18 Cumulative plastic deformation rate of column

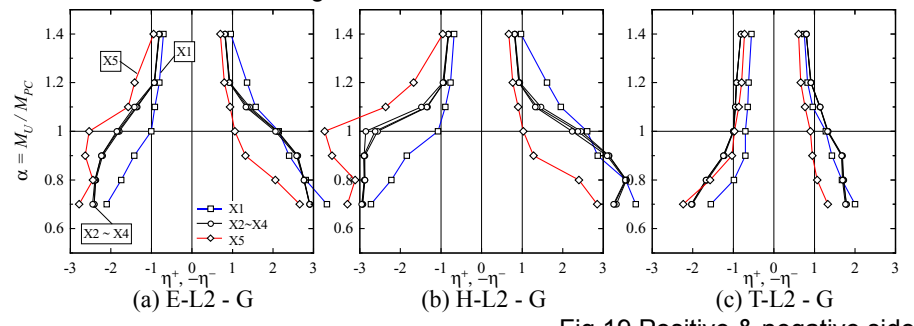

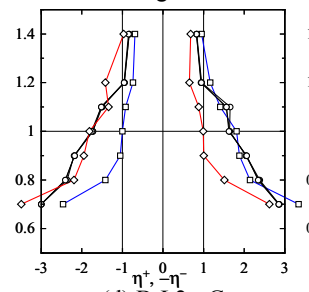

(d) $\mathrm{B}-\mathrm{L} 2-\mathrm{G}$

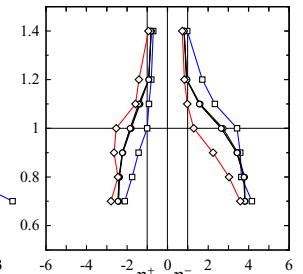

(e) $\mathrm{E}-\mathrm{L} 3-\mathrm{n}$

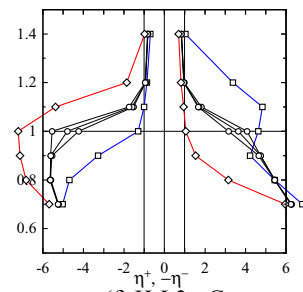

(f) $\mathrm{H}-\mathrm{L} 3-\mathrm{G}$

Fig.19 Positive \& negative side plastic rate of column-base

\section{2 露出柱脚周辺の挙動}

図 19 より, 中柱 (X2 X4) の塑性率はほぼ差異が無いが，側柱 (X1， X5）の塑性率には大きな差異が生じている.これは, 図 22, 20 に見 られるように変動軸力が作用し，図 21,20 に見られる柱脚の曲げ而 力や曲げ剛性の差異に基因したものである.
更に，側柱では柱軸力の変動による柱脚と柱の曲げ而力増減によ

り, 載荷方向で降伏要素が変化することが図 20,21, 23 より読み取れ る. 具体的には図 28 に示す挙動となり, X5 を例とすると, 正方向 では柱軸力が圧縮側に増大し柱が降伏，負方向では柱軸力が引張側 に増大し柱脚が降伏するものである.図 17, 18 と図 19 から,この現 

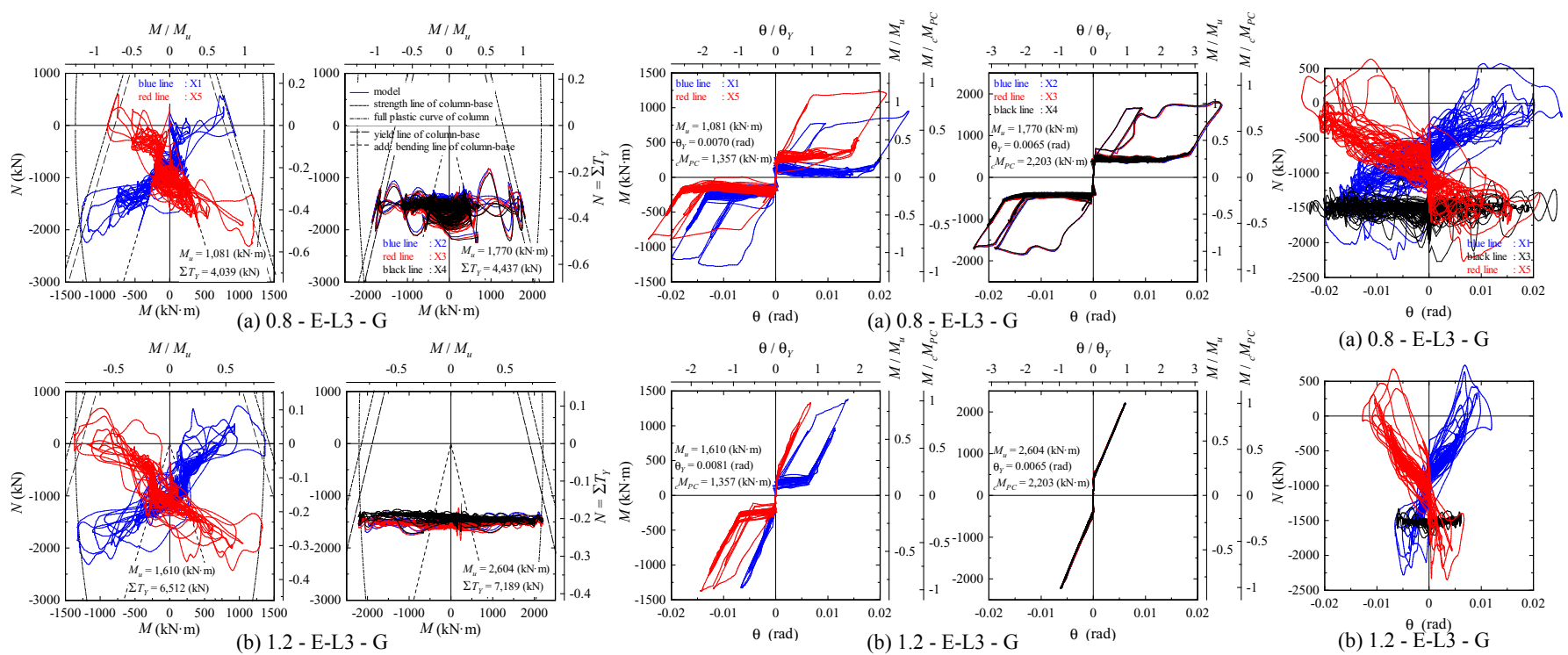

$\sum \Sigma^{2}$

(a) 0.8 - E-L3 - G

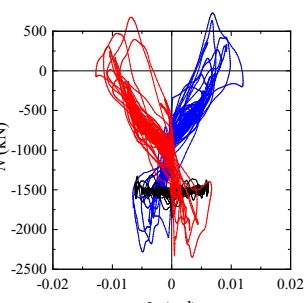

(b) $1.2-{ }^{\theta}$ - $\mathrm{E}-\mathrm{Lad} 3-\mathrm{G}$

Fig. $21 M-\theta$ relation for column-base

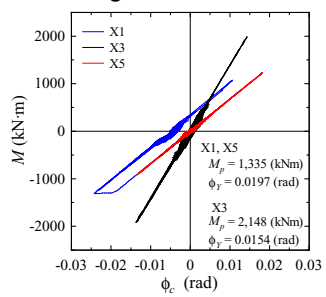

(a) $0.8-\mathrm{E}-\mathrm{L} 3-\mathrm{G}$

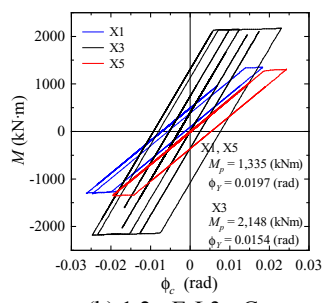

(b) 1.2 - E-L3 - G

Fig. $23 M-\phi_{c}$ reration for column

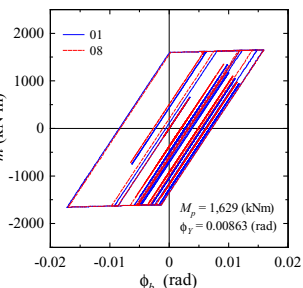

(a) 0.8 - E-L3 - G
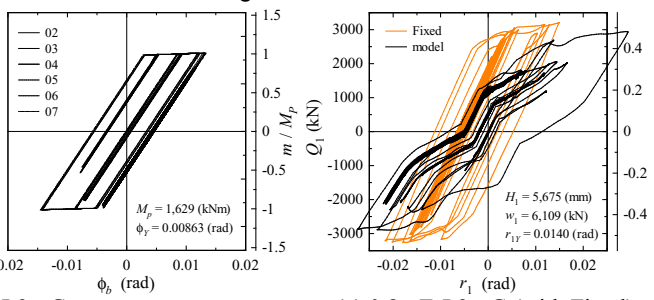

(a) 0.8 - E-L3 - G (with Fixed)

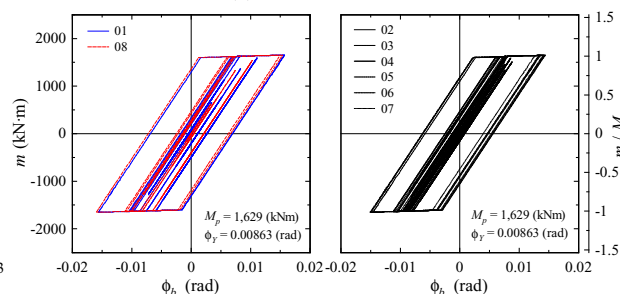

(b) 1.2 - E-L 3 - G

Fig.24 $m-\phi_{b}$ reration for beam

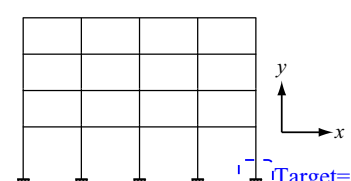

$M, \theta, N, r_{1}$
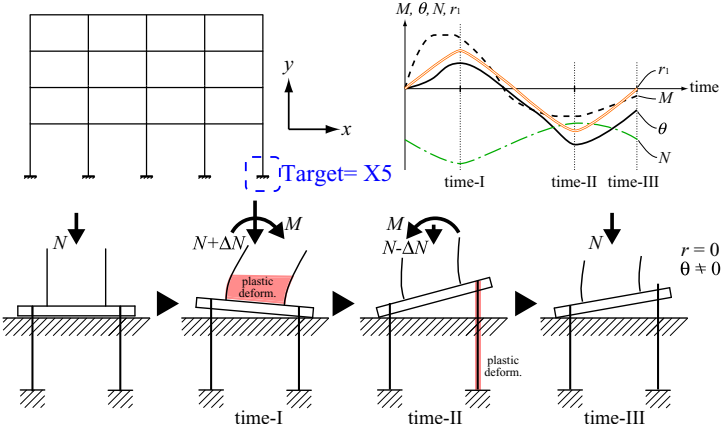

Fig.28 Image of yield element changed by variable axial force ( X5 )

象は本論文の対象構造物においては $\alpha=0.8 \sim 1.2$ で現われている.

\section{3 第一層上梁の塑性変形}

図 $15,16,24$ より，側柱に設置された 01,08 と中柱に設置された 02 07 とでは塑性率など変形量が異なる。一方，側柱においては，露 出柱脚に見られたような差異（01 と08 とで履歴形状や変形量が異な るような傾向）は見られない.

\section{4 第一層応答と回転剛性について}

図 25 より, $\alpha=0.8$ では架構 (梁) が示す紡錘型と柱脚のダブルフラッ グ型の履歴形状が混合した履歴形状を示している. $\alpha=1.2$ では, 図 26 の1 の正方向またはX5 の負方向に, 同じく柱脚の復元力特性の

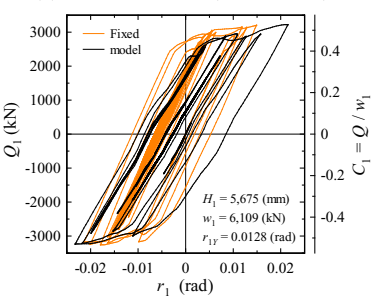

(b) 1.2 - E-L3 - G (with Fixed) Fig.25 $Q_{1}-r_{1}$ reration

\section{5. 露出柱脚付構造物の設計に対する}

\section{1 柱軸力の変動と柱脚挙動}

\subsection{1 梁のせん断力（側柱に着目）}

Fig.22 $N-\theta$ relation for column-base

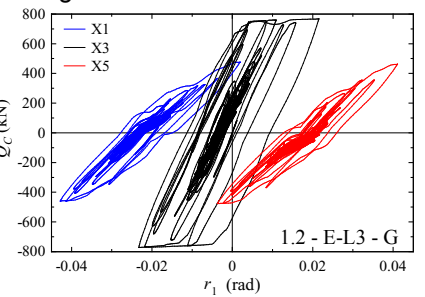

Fig.26 $Q_{C}-r_{1}$ relation

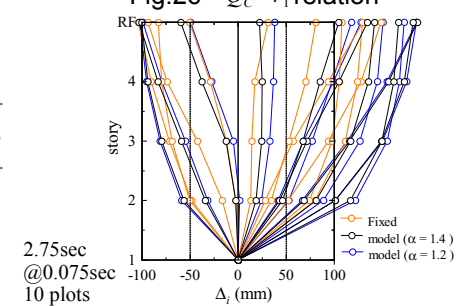

Fig.27 Deformed each time

(1.4 - E-L3 - G (with Fixed) )

影響が含まれるため, 紡錘型を若干崩したような形を示す.

次に, 図 27 に示すように $\alpha=1.2$ であっても固定端の結果と全く 整合しておらず，鋼構造接合部設計指針 ${ }^{23)}$ に示されるように露出柱 脚を半剛接合として設計することの重要性が確認できる.

柱軸力の変動について, 代表的な要因毎に検討を行う.

図 29 に示すように, 地震応答時においては梁のせん断力は柱軸力 として作用する。また， 1 次モードで振動している場合は，層方向の 全梁が降伏している状態を対象として考え，柱下端に作用する最大・ 最小柱軸力 $N_{\max }, N_{\min }$ は以下の式で定義できる.

$$
N_{\text {min, } \max }=N_{D} \pm \sum_{i=1}^{n}\left(Q_{L i}-Q_{R i}\right)=N_{D} \pm \sum_{i=1}^{n} 2\left(\frac{M_{P L i}}{L_{L}}-\frac{M_{P R i}}{L_{R}}\right)
$$

ここに, $N_{D}$ : 構造物自重による柱軸力, $Q_{L i}, Q_{R i}$ : 任意柱 $i$ 層左右梁 から作用する梁せん断力, $M_{P L i}, M_{P R i}$ : 任意柱 $i$ 層左右梁の全塑性耐力, $L_{R}, L_{L}$ : 任意柱に対して右側および左側の構造物スパン長である.

表 4 に梁の全塑性耐力を, 表 5 に各柱の構造物自重による柱軸力 および最大・最小柱軸力を示す. 尚, 中柱では左右の梁のせん断力 
Table 4 Full yield strength Table 5 Dead load and maximum

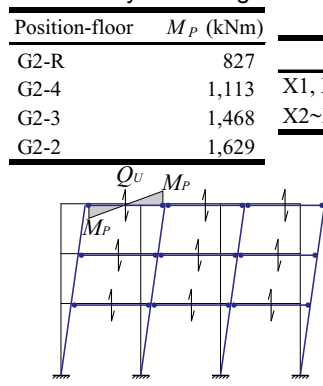

(a) Global

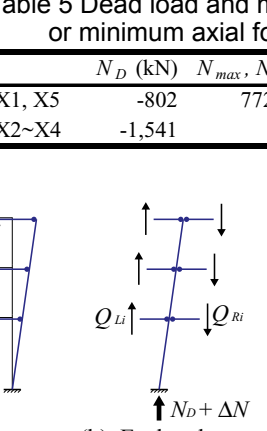

(b) Each column

Fig.29 Collapse mechanism for frame

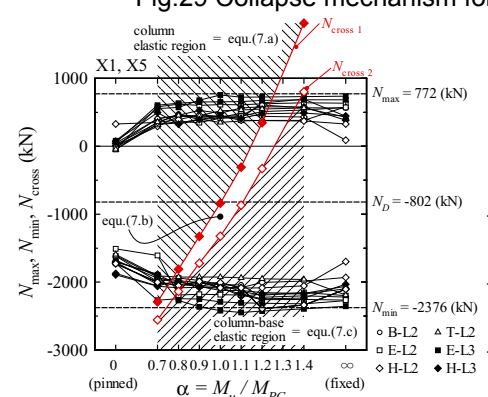

$\alpha=M_{u} / M_{P C}$
(a) X1, X5

Fig. $32 N_{\mathrm{n}}$

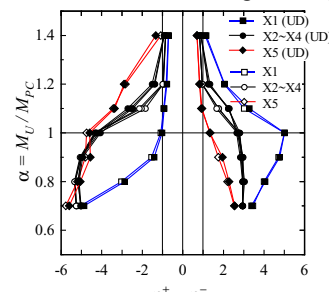

(a) JMA - UD \& G

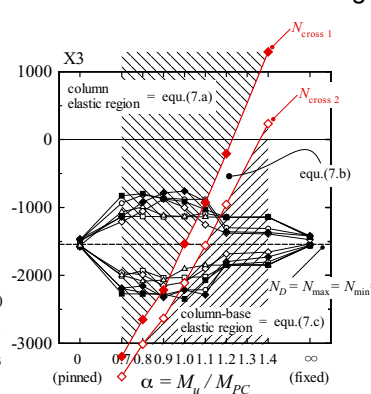

$\alpha=M_{u} / M_{P C}$
(b) $\mathrm{X} 3$

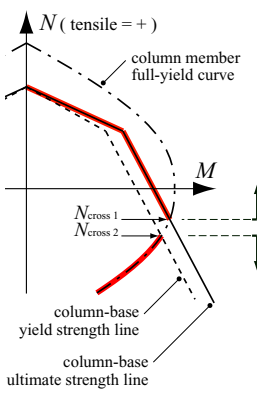

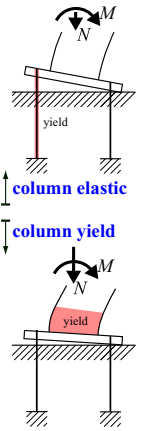

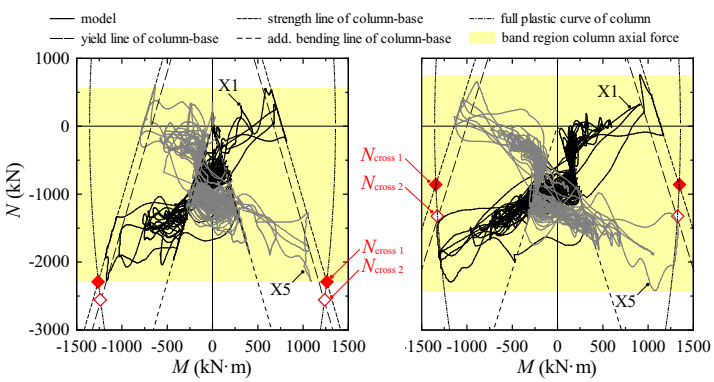

(a) $N$ ros out variable axial force range (0.7 - E-L3 - G)

(b) $N_{\text {cross }}$ in variable axial force range (1.0 - E-L3 - G)
Fig.30 $M-N$ interrelation curve Fig.31 Examination of cross changed point with variable axial force range

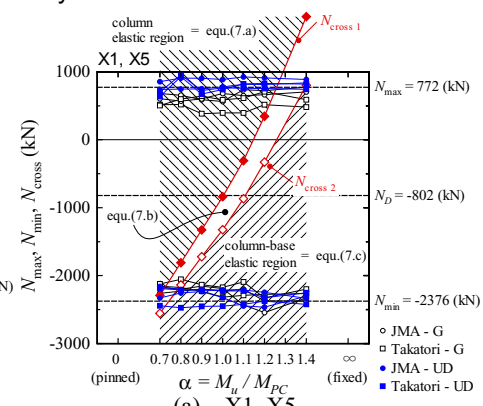

$\alpha=M_{u} / M_{P C}$
(a) X1, X5

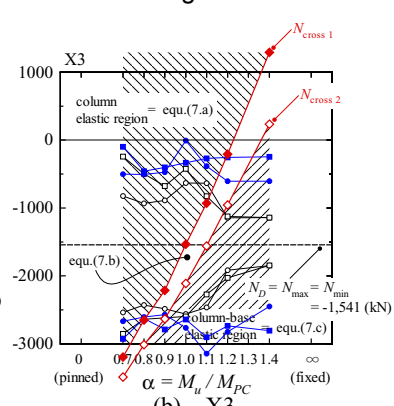

$\alpha=M_{u} / M_{P C}$
(b) $\mathrm{X} 3$

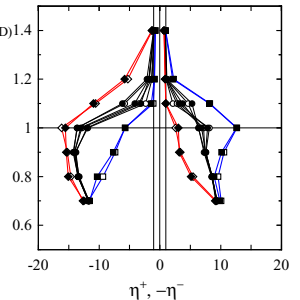

(b) Takatori - UD \& G side plastic rate of column-base (Ana. II)

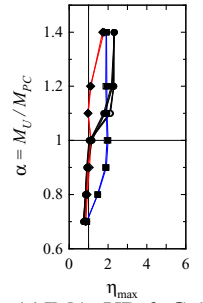

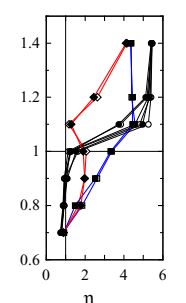

$\eta_{\max }$

Fig.35 Plastic rate of column (Ana. II)

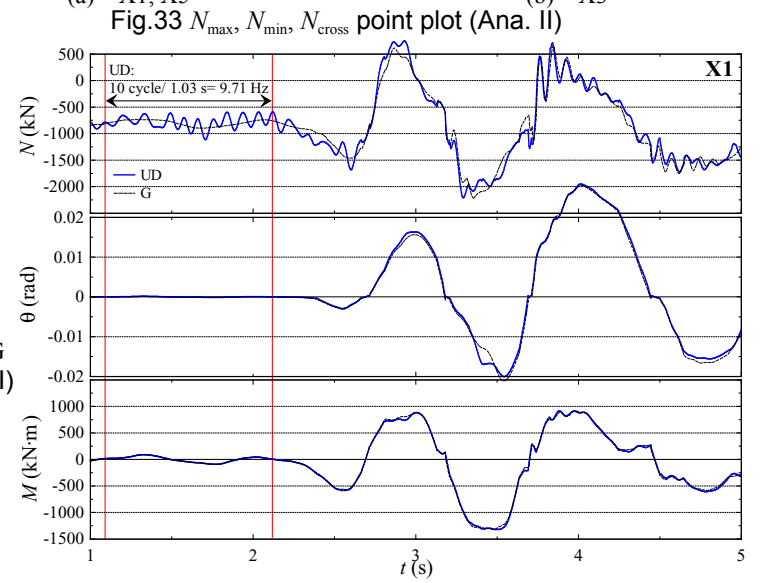

Fig.36 Time history of column-base (Ana. II, 0.8 - JMA - UD)

$Q_{R i}, Q_{L i}$ が相殺し合うため柱の軸力変動は生じないものとする.

一方, 図 30 の $M-N$ 耐力相関関係上に定義している $N_{\text {cross } 1}, N_{\text {cross } 2}$ と 式 (6) から得られる值より, 降伏要素は以下のように判断できる.

$$
\begin{array}{ll}
N_{\text {cross } 1}<N_{\text {min }} & : \text { 柱弾性 } \\
N_{\text {min }} \leq N_{\text {cross } 1,}, N_{\text {cross } 2} \leq N_{\text {max }} & : \text { 柱および柱脚共に非線形化 } \\
N_{\text {max }}<N_{\text {cross } 2} & : \text { 柱脚弾性 }
\end{array}
$$

図 31 に $M-N$ 耐力相関関係解析結果と $N_{\text {cross } 1,} N_{\text {cross } 2}$ 位置の具体例を 示す. $N_{\text {cross } 1,}, N_{\text {cross } 2}$ は $\alpha$ に依存して大きく変化する. 更に, 柱軸力 の変動する領域内に $N_{\text {cross } 1}$ または $N_{\text {cross } 2}$ が存在する場合, 式 (7.b) に 該当するため図 28 の挙動が現われる.

次に, $N_{\text {cross } 1,} N_{\text {cross } 2}$ の変遷と, 式(6)より算出した $N_{\max }, N_{\min }$ の対 応を検討する. 図 32 に解析 I $の ~ \alpha$ 毎の $N_{\max }, N_{\min }, N_{\text {cross } 1}, N_{\text {cross } 2}$ の分 布を示す. 同図中には, $N_{D}$ および式(6)により算出した值を破線で, 右下ハッチで式(7.a)の領域を, 右上ハッチで式(7.c) の領域を, 併 せて示す. 図 32 (a) より, 側柱の $N_{\text {max }}, N_{\text {min }}$ は式(6)の值を上限およ び下限值と対応した分布となっている. そして, $N_{\text {cross } 1,} N_{\text {cross } 2}$ と $N_{\text {max }}$, $N_{\min }$ の相対的関係から, $\alpha=0.7$ は式 (7.a), $\alpha=0.8 \sim 1.2$ は式 (7.b), $\alpha=1.4$ は式 (7.c) に該当する.これは図 17 21, 23 の結果と整合している.

尚, 式 (6) の構成から, 中柱においても

・左右の構造スパンが極端に異なる.

・左右の梁成が極端に異なる。

等の場合, 梁のせん断力差による柱軸力変動が生じる.

\subsection{2 ベースプレートと基礎との衝撃力（中柱に着目）}

図 32 (b) より, 中柱でも柱軸力の変動は生じている. これは, 回 転離間したベースプレートと基礎とが再接触するときの衝撃力によ るものであり，変動幅は最大で $\pm 800 \mathrm{kN}$ 程度と小さくはない，しか しながら図20(a)のX3 より, 原点通過直後に柱軸力の変動が発生す るが, 塑性変形が進展する変形時には $N_{D}$ に収束し(儗A), 柱および柱 脚の塑性変形に殆じ影響を与えない。これは, 図 17 21, 23 において, $\alpha=0.7 \sim 0.9$ で柱脚のみが降伏, $\alpha=1.0 \sim 1.1$ で柱および柱脚が共に降伏, $\alpha=1.2 \sim 1.4$ で柱のみが降伏している点, 図 32 (b) の $N_{D}=N_{\max }=N_{\min }=$ 破線 と $N_{\text {cross } 1}, N_{\text {cross } 2}$ との相対関係, 図 17 19の結果が対応する点と整合する. 従って, ベースプレートと基礎との再接触時の衝撃力により柱軸 力の変動は生じるが，柱および柱脚の曲げ耐力・曲げ変形を検討す る折には，考慮しなくても良いと判断できる.

\subsection{3 地震動鉛直成分}

解析 II $の$ 結果として, 図 33 に $\alpha$ 毎の $N_{\max }, N_{\min }, N_{\text {cross } 1}, N_{\text {cross } 2}$ の 分布を, 図 34 に露出柱脚の正方向および負方向塑性率 $\eta^{+}, \eta^{-}$を, 図 35 に第一層柱下端部の最大塑性率を, 図 36 に側柱 X1 の柱軸力 $N$, ベースプレート回転角 $\theta$, 柱脚曲げモーメント $M$ 時刻歴を示寸. 


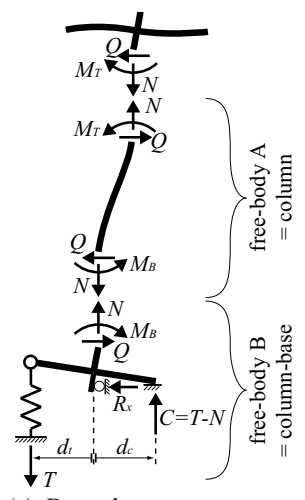

(a) Base plate contact to foundation ( condition A) Fig.37 Working stress for column-base \& column

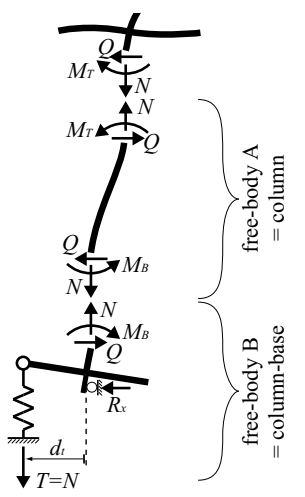

(b) Base plate separate from foundation ( condition B )

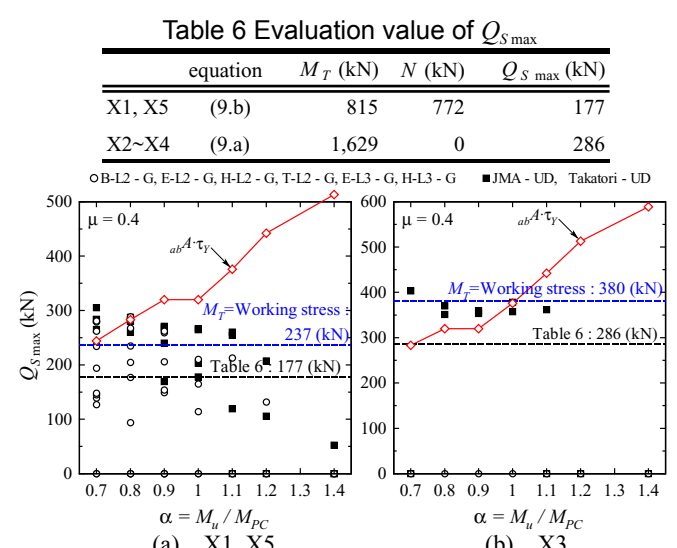

$\alpha=M_{u} / M_{P C}$
(a) $\mathrm{X} 1, \mathrm{X} 5$

Fig.38 $Q_{S}$ plot of time history analrysis (Ana. I \& II)

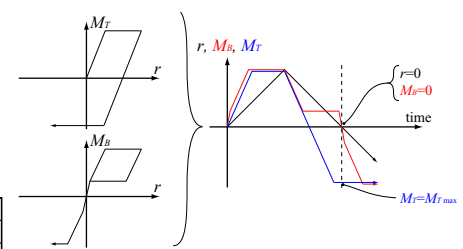

(a) Column-base yield type

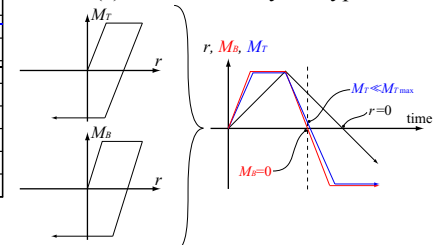

(b) Column yield type

Fig. $39 M_{T} \& M_{B}$ time history
図 33 より, G に比較して UD の変動域は広く, 式 (6)の範囲を超 過している。一方, 図 34, 35 より, G および UD の結果は, ほぼ一 致している. これらは, 図 36 より UDによる $N$ の増減で $\mathrm{G}$ に対し て $\theta$ と $M$ も一次的に増減するが, 構造物の固有值 $(1.12 \mathrm{~Hz})$ に比較 してUD の振動数が高く $(9.71 \mathrm{~Hz}), \mathrm{UD}$ が構造部材の水平応答に基 因した柱脚周辺の塑性変形に寄与し難いためと考えている. 従って, 鉛直方向加速度は, 重力加速度のみの考慮で良いと判断できる.

尚，およそ $10 \mathrm{~Hz}$ の振動に対して時間刻み 0.005 秒の分解能は低い が, 別途 0.0005 秒刻みの解析を行い整合する結果を確認できている.

\section{2 アンカーボルトに作用するせん断カ}

先ず, 露出柱脚におけるせん断力に対する抵抗要素は, ベースプ レートと基礎間の摩擦力 $Q_{f}$ と, アンカーボルトのせん断抵抗力 $Q_{s}$ に 大別される. 但し両者の抵抗剛性は大きく異なり, 設計ではそれぞ れ個別に算定して大きい值が採用される ${ }^{23)}$.ここでは, 実際の抵抗 状態，並びに設計指針での扱いを鑑みて，柱脚に作用する水平方向 の反力 $R_{x}$ を, 以下のように $Q_{f}$ または $Q_{s}$ として読み替える.

$$
\begin{array}{lll}
Q<Q_{f}=C \cdot \mu & \Rightarrow R_{x}=Q_{f} \\
Q_{f} \leq Q & \Rightarrow & R_{x}=Q_{s}
\end{array}
$$

ここに, $C$ : 基礎とベースプレート間の接触力, $\mu:$ ベースプレート と基礎間の摩擦係数である.

本節では, 解析 I, II の結果を用いて, 式 (8.b)により得られるアン カーボルトに作用するせん断力 $Q_{s}$ の最大值について検討を行う.

先ず, 図 37 に露出柱脚付柱の柱脚・柱頭回りの応力を示す.

図 37 (a) の free-body A から, 柱せん断力を柱頭, 柱脚の存在曲げ 応力 $M_{T}, M_{B}$ を用いて表し, 更に, $M_{B}$ を $T$ と $\left(d_{c}+d_{t}\right)$ により表現できる. そして, 図 37 (b) の free-body B から, 接触による摩擦力がない場合, $M_{B}$ は $T=N$ と $d_{t}$ により表現できる．それぞれを以下に示す．

condition A : $0<C=T-N \quad \therefore N<T$

$$
Q_{S \max }=\frac{M_{T}+M_{B}}{H}=\frac{M_{T}}{H}+\left\{T \cdot\left(d_{c}+d_{t}\right)-N \cdot d_{c}\right\} \cdot \frac{1}{H}
$$

$$
\text { condition } \mathrm{B}: T=N \quad(0<N)
$$

$$
Q_{S \max }=Q=\frac{M_{T}+M_{B}}{H}=\frac{M_{T}}{H}+N \cdot \frac{d_{t}}{H}
$$

但し， $C$ が大きくなると式 (8.a) の判定となるので, $T=0$ とする. これ等から得られる值を表 6 に示寸. X1, X5 の $N$ は表 5 中の最大值, X2 X4 の $N$ は図 33(b) を考慮して 0 とする. $M_{T}$ は節点振り分け法に より各節点の梁の全塑性耐力総和の半分としている.

ここで, 式(8.b)により算定した存在応力 $Q_{S}$ の最大值を図 38 に示し, 表 6 中に記した $Q_{S \text { max }}$ を併記する.
図 38 より, 先ず, $Q_{S \text { max }}$ は側柱では $\alpha=1.2$, 中柱では $\alpha=1.1$ を超 過すれば極端に低下寸る。これは, 図 39 に示すように柱降伏型であ れば柱脚周りの履歴形状が完全弾塑性型となり, $T=0\left(M_{B}=0\right)$ の時に $M_{T}$ が小さく, それ以外は $T$ が生じることで $Q_{S}$ が減少するためである.

次に, 各結果は表 6 の值を超過している.これは, $M_{T}$ が表 6 中の 值を超過しているためであり, 実際に作用した応力で再計算した結 果 (X1, X5 : $237 \mathrm{kN}, \mathrm{X} 3: 380 \mathrm{kN}$, ) は解析結果に対応している.

以上, 式 (9.a), (9.b)により $Q_{S \text { max }}$ を評価でき, また中柱において も $Q_{S}$ は存在することが分かる. 但し, その值は最大でもアンカーボ ルト一本の降伏せん断力 ${ }_{a b} A \cdot \tau_{Y}$ をやや超過する程度であり, 圧縮側 アンカーボルト群の降伏せん断耐力を下回ることは明らかである.

\section{3 露出柱脚の弾性回転剛性と柱の水平剛性}

本節では露出柱脚を半剛接合として設計する必要性を明確にする ため, 図 40 に示すように第一層の柱を, 単一柱上下に回転バネを有 する略算モデルへと置換し, 露出柱脚の回転剛性と柱の水平剛性 $K$ の相関関係を追跡する. 上端の回転バネ $k_{T}$ は柱左右に取り付く梁の 曲げ剛性により定義し, 下端の回転バネ $k_{B}$ は露出柱脚の割線回転剛 性 $K_{S}$ （表 2, 図 8 参照）とする. また, 柱の曲げ剛性 $E I_{C}$ を表す值を $k_{C}=E I_{C} / H$ と定義する.

図 40 (b) の変形状態より, 柱の水平剛性 $K(=P / \delta)$ を各回転剛性 $k_{C}$, $k_{B}, k_{T}$ で表現すれば以下となり, 架構の水平剛性を評価できる.

$$
K=\frac{12}{H^{2}} \cdot \frac{\frac{1}{k_{C}}+\frac{1}{k_{B}}+\frac{1}{k_{T}}}{\frac{1}{k_{C}^{2}}+\frac{4}{k_{C} \cdot k_{B}}+\frac{4}{k_{C} \cdot k_{T}}+\frac{12}{k_{B} \cdot k_{T}}} \quad \ldots\left(k_{C}=\frac{E I}{H}\right)
$$

$k_{T}, k_{B}$ が柱の水平剛性に及ぼす影響を検討するため, 図 41 に $k_{T}$ を 変数とした柱の水平剛性 $K$ - 柱脚回転バネ剛性 $k_{B}$ 関係を示す. 尚, 各值は式 (10) を利用して算出し, また, 縦軸は両端固定柱の水平剛 性で無次元化, $k_{B}, k_{T}$ は柱の $k_{C}$ で無次元化している. 図 41 より, $K$ が大きく変動する領域は $k_{T}$ によらず, $0.1<k_{B} / k_{C}<100$ である.

次に, 柱脚を固定端とした場合の水平剛性 $K_{f i x}$ は, $k_{B}=\infty$ を式 (10) に代入して, 以下のように表現される。

$$
K_{f i x}=\left.K\right|_{k_{B}=\infty}=\frac{12}{H^{2}} \cdot \frac{\frac{1}{k_{C}}+\frac{1}{k_{T}}}{\frac{1}{k_{C}^{2}}+\frac{4}{k_{C} \cdot k_{T}}}
$$

更に, $K$ と $K_{f i x}$ の比を表す值を $\alpha_{d}\left(=K / K_{f i x}, 0<\alpha_{d}<1\right)$ と定義し, 図 42 に $\alpha_{d}-k_{B}$ 関係を示寸. 図 42 より, 各曲線は $k_{B}$ が大きくなるにつ れて収束する傾向にあり, 図 42 (b) に示した $10<k_{B} /(E I / H)$ の領域で は概社重なっている. 寸なわち, 図 42 (b) に示す領域では各曲線は 


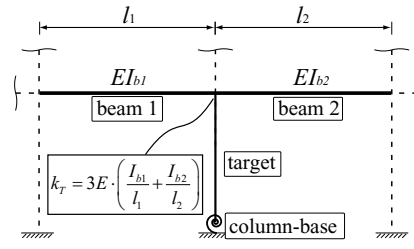

(a) Target $\& k_{T}$

Fig.40 Abbreviated calculation model
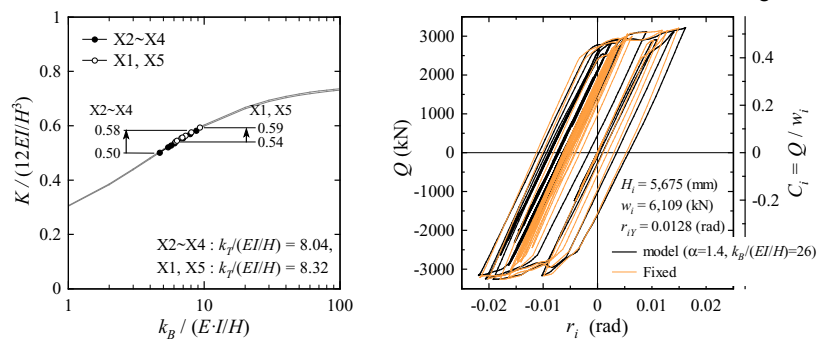

Fig.44 $Q_{1}-r_{1}$ relation ( E-L3 - G )

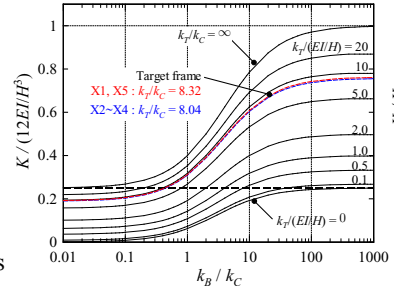

Fig.41 $K-k_{B}$ relation

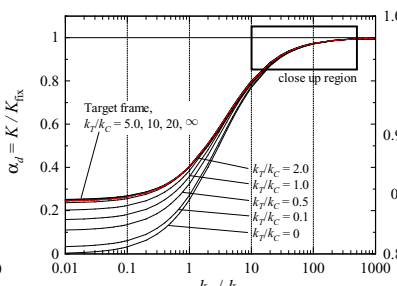

(a) Global

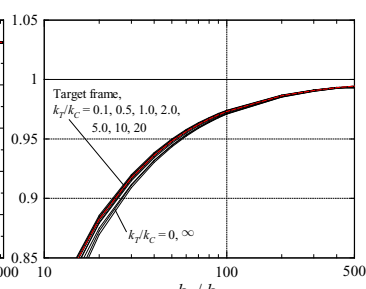

(b) Close up region

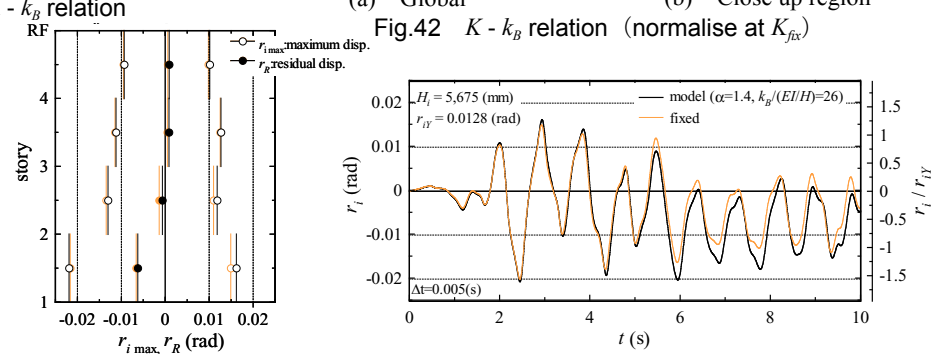

Fig.45 Maximum \& residual story drift angle ( E-L3 - G)
Fig.46 1st story drift angle time history ( E-L3 - G )

$k_{T}$ に対して独立な状態に近いと判断できる. 柱の曲げ剛性 $E I$ と柱脚 回転剛性 $k_{B}$ 間の関係性のみで議論するため, $k_{T}=\infty$ を用いて同関係 式と範囲を以下に定義する. 尚, 当該式を満足するとき $k_{B}=\bar{k}_{B}$ と表す.

$$
\left.\alpha_{d}\right|_{k_{T}=\infty}=\frac{K}{K_{f i x}} \Rightarrow \quad \overline{k_{B}}=k_{C} \cdot \frac{4 \alpha_{d}-1}{1-\alpha_{d}} \quad\left(0.9 \leq \alpha_{d} \leq 1.0\right)
$$

以上を利用して,$k_{B}$ が有限であっても $K$ が $K_{f i x}$ の 9 割の水平剛性 を確保 $\left(=\alpha_{d}=0.9\right)$ できる場合を考えると，

$$
\left.\overline{k_{B}}\right|_{\alpha_{d}=0.9}=k_{C} \cdot \frac{4 \times 0.9-1}{1-0.9} \simeq 26 k_{C}
$$

となる.このように, $K_{f x}$ に対して 9 割の水平剛性を得る, 寸なわち, 剛性の観点から固定端に近しい状態を得るために必用な露出柱脚の 回転岡性值を，柱の曲げ剛性を用いて明確に定められる.

ここで, 本研究の解析対象を利用して一般的なディテールの挙動 を検討する. 図 43 に $K-k_{B}$ 関係上に式(10) と表 2 中の $K_{S}$ を用いて 算出した中柱 $(\mathrm{X} 2-\mathrm{X} 4)$ と側柱 $(\mathrm{X} 1, \mathrm{X} 5)$ の各 $\alpha$ の剛性分布を示す. 露 出柱脚の耐力に着目した変化 $\alpha=0.7 \sim 1.4$ に対して, 水平剛性に与える 変化の割合は 1 割り以下である. 更に, $\alpha=1.4$ の柱脚であっても固定 端とした場合の 6 割程度の水平剛性しか有しておらず，これは 4.4 節 の結果や，文献 23) で半剛接合として扱われていることと整合する.

次に，式 (13)を追跡するため，図 44 46に $\alpha=1.4$ として式(13)を 満足する回転剛性を露出柱脚に与えた架構の解析結果の一例を示す. 図 44 46より, 式(13)の条件を満足することで, 固定端の結果と整 合している. 寸なわち, 式(10)によって露出柱脚の弾性回転の影響 を明解に定義・議論できることが示された。

最後に, 図 9 に示すように, 付加曲げ領域の回転剛性 $K_{n}$ は式 (13) を超過する值を得ている，基礎コンクリートを用いた場合にあって も，これと同様に式(13) を超過する回転剛性が得られるのであれば, $K_{n}$ に無限の剛性を与えることは妥当である.

\section{4 露出柱脚挙動と第一層上梁の弾性変形}

図 40 のモデルを用いて, 露出柱脚挙動が第一層上梁に与える影響 を吟味する. 先ず，図 40 (b) のモデルにおける任意回転バネ 1 の回 転量 $\theta_{1}$ は, 式 (10) を変形して以下の式で表現できる。

$$
\theta_{1}=r \cdot 12 \cdot \frac{\frac{1}{2} \cdot \frac{1}{k_{C} \cdot k_{1}}+\frac{1}{k_{1} \cdot k_{2}}}{\frac{1}{k_{C}^{2}}+\frac{4}{k_{C} \cdot k_{1}}+\frac{4}{k_{C} \cdot k_{2}}+\frac{12}{k_{1} \cdot k_{2}}}
$$

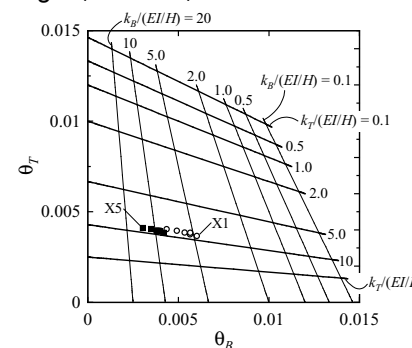

(a) Global

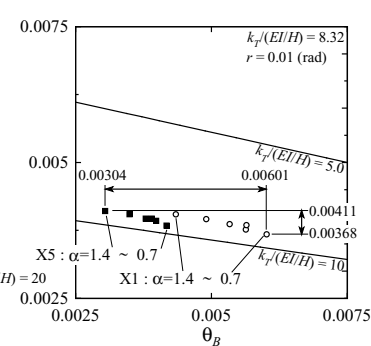

(b) Plotting area

ここに, $k_{1}$ : 回転角算出対象とする回転バネの回転剛性, $k_{2}$ : もう 一方の回転バネの回転剛性である.

図 47 に, 式 (14) を用いて算出した $r=0.01(\mathrm{rad})$ 時の $k_{T}$ 一定または $k_{B}$ 一定の直線を示す. また, 静的荷重増分解析時における第一層層 間変形角 $r_{1}=0.01(\mathrm{rad})$ 時の X1 または X5 のベースプレート回転角を $\theta_{B}$, 第一層柱上部の節点角を $\theta_{T}$ として, 図 47 上に併せて示す.

図 47 より, 一方の回転剛性の変化が他方の回転角へ与える影響は 緩慢であることが分かる. 具体的には, X1 とX5 との回転角の分布は, $\alpha$ による回転剛性の変化により $\theta_{B}=0.00304 \sim 0.00601$ の範囲に分布す るが, $\theta_{T}=0.00368 \sim 0.00411$ であり, $k_{B}$ や $\theta_{B}$ が倍半分増減しても, $\theta_{T}$ は 1 割程度しか変化しない。これは, 4.2 節で議論した側柱に取り付 く梁の変形量に差異が無い結果に整合している.

\section{5 露出柱脚の最大回転角と第一層最大層間変形角}

図 40 のモデルを用いて, 弾塑性領域を含んだ露出柱脚の最大回転 角の追跡を行う. 但し，第一層の最大層間変形角が既知であること を基本条件とする。

先ず，図 40 のモデルにおける上下端回転バネの弾塑性挙動は bilinear 型に単純化する. 上端については $k_{T}$ の回転剛性, 耐力は表 6 の 值を $M_{T Y}$ に据える. 下端については, 図 48 に示すように設定する. 柱軸力が変動する場合は, 回転角が大きくなる引張側の軸力 $\left(=N_{\text {max }}\right)$ を採用し，同軸力が回転角の増大と同時に発生するとし，この時の 復元力特性から原点と降伏点を結ぶ割線回転剛性 $K_{S}$ を $k_{B}$ に, 最大耐 力 ${ }_{a b} M_{U}+\overline{M_{n}^{\prime}}$ を $M_{B Y}$ に据える.

次に，任意回転バネの回転角は式 (14)により算出できるが，弾塑 性領域における分岐等を定めるため, 以下の場合分けをする. 先ず, 柱脚降伏型である場合, 


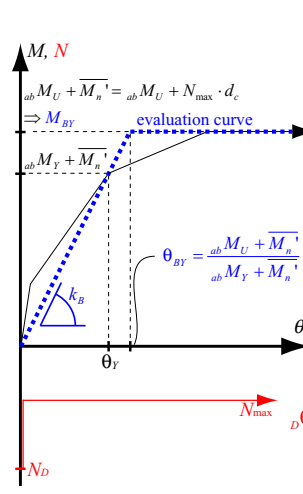

Fig.48 Exposed columnbase hysteresis \& $k_{B}$

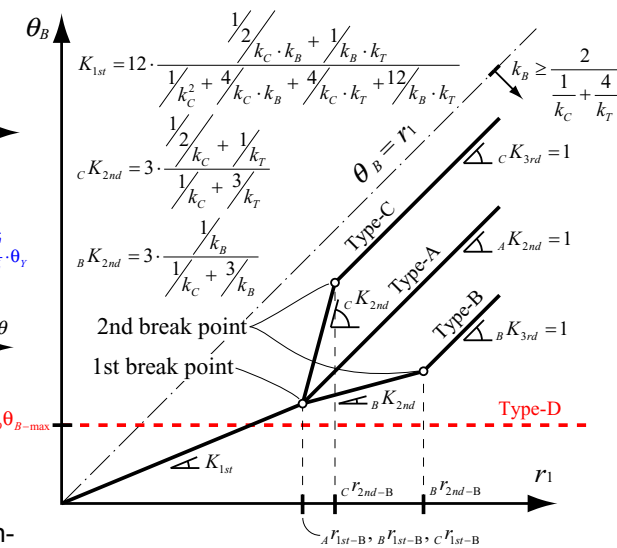

Fig.49 $\theta_{B}-r_{1}$ relation evaluation method

$$
\begin{aligned}
& \frac{M_{B Y}+2 k_{C} \cdot \theta_{B Y}}{M_{T Y}+2 k_{C} \cdot \theta_{T Y}}=1.0: \text { Type-A }=\text { 上下回転バネ同時降伏 } \\
& \frac{M_{B Y}+2 k_{C} \cdot \theta_{B Y}}{M_{T Y}+2 k_{E} \cdot \theta_{T Y}}>1.0: \text { Type-B }=\text { 上端回転バネ先行降伏 } \\
& \frac{M_{B Y}+2 k_{C} \cdot \theta_{B Y}}{M_{T Y}+2 k_{C} \cdot \theta_{T Y}}<1.0: \text { Type-C }=\text { 下端回転バネ先行降伏 } \\
& \text { となる. 一方, 柱降伏型は以下で判断できる. } \\
& \frac{M_{B Y}}{{ }_{C} M_{P C}} \geq 1.0: \text { Type-D } \quad=\text { 柱降伏型 }
\end{aligned}
$$

図 49 に, これら 4 種類の場合分けについて，それぞれの条件にお ける分岐位置と第一層層間変形角 $r_{1}$ との関係式を併記する. 同図中 における，各分岐位置， $\theta_{B}$ 算出式は付録 B にまとめる.

図 49 に従えば，層間変形角に対応した $\theta_{B}$ を弾塑性領域で追跡で きる.例として, 図 50 に解析 I の 0.7 - E-L3 - G の X1 における $\theta_{B}-r_{1}$ 関係之評価曲線を併記する. 比較のため時刻歴応答解析においては, 正方向の最大層間変形角が発現する $3.0(\mathrm{~s})$ までの履歴を示している が，当該履歴に対して，青破線の評価折孔線は履歴と重なっており， 評価手法が対応していることが分かる.

ここで，図 51 に解析 $\mathrm{I}$ の最大層間変形角を用いて算出した $\theta_{B}$ の評 価值と, 同時刻歴応答解析結果の比を示す。尚, 同図中下端には式 (15.a d) の判定結果を明記する. また，式 (7.b) に該当する（図 28 の 挙動が現われる）場合は，繰返し載荷下の累積塑性変形を考慮して いない本節の手法では評価できないため, 当該領域を適用範囲外之

して黄色ハイライトで記している.

先ず, 中柱 $\alpha=0.7,0.8,1.2,1.4$, 側柱 $\alpha=0.7$ は誤差 1 割程度で対応 している. 一方, 側柱 $\alpha=1.4$ は算定值が最大で 1.28 倍と過大に評価 しているが，これは解析には柱の全塑性耐力まで達していない結果 が含まれており，解析結果の回転角が小さくなることに基因してお り，評価精度が低いためではない。このように，本項の評価方法が 適用できる場合は，簡便に $\theta_{B}$ を追跡することができる。

最後に，図 49, 50 から読み取れるように，柱脚回転角は層間変形 角と $1: 1$ の比例直線以下の領域に位置している. 従って, 柱脚降伏型 においては柱脚最大回転角を最大層間変形角とすることで，安全側 に予測できる．但し， $k_{B}$ が一定值以下であると上記を満足しなくな る. 端的に表現すると上端固定，下端ピンの柱がこれに該当し， $r_{1}<$ $\theta_{B}$ となる. 比例直線以下の領域に位置する条件は, 式 (14) に $\theta_{1}=\theta_{B}$ $=r=r_{1}$ を代入して $k_{B}$ に着目した以下の式となる.

$$
k_{B} \geq \frac{2}{\frac{1}{k_{C}}+\frac{4}{k_{T}}}
$$

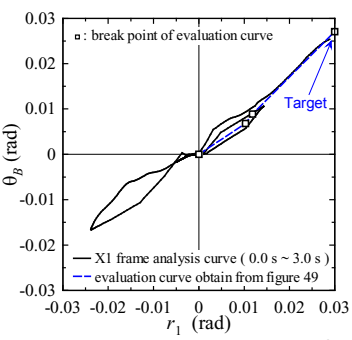

Fig.50 Analysis results \& evaluation curve on $\theta_{B}-r_{1}$ relation

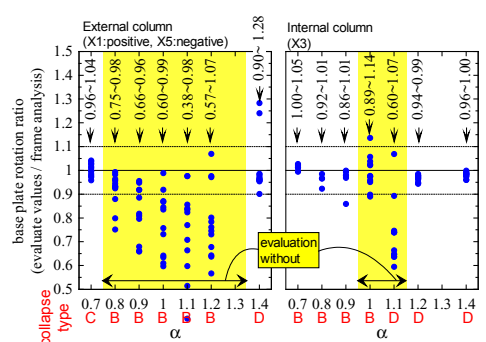

Fig.51 Evaluation / Analysis for $\theta_{B}$

\section{6 結論}

露出柱脚を有する 4 層鋼構造物平面ラーメン架構の時刻歴地震応 答解析を実施し, 応答解析結果および力学モデルから, 地震時にお ける露出柱脚挙動に注目した検討を行った. 露出柱脚を構造的に理 解する上で, 存在応力の捉え方, 变形挙動と周辺への影響等を議論し, 得られた知見を以下にまとめる.

1. 側柱の露出柱脚には，4 層程度の架構であっても構造特性を著 しく変化させる量の柱軸力の変動が生じる．この結果，本論文の 対象構造物にあっては, 柱と露出柱脚の耐力比が $0.8 \sim 1.2$ の範囲で, 載荷方向によって降伏要素が変化する図 28 の現象が見られた.

次に, この柱軸力の変動幅は 1 次モードで振動する構造物にあっ ては式 (6) で簡便に定めることができる．当該変動幅と，柱と柱 脚の $M-N$ 耐力曲線を用いれば，図 28 の挙動が生じるか否かを判 断できる。

2. ラーメン架構においては水平応答の振動数に比較して, 鉛直方 向加速度応答は高い振動数を示寸．このため, 鉛直方向加速度は 水平応答に基因した柱脚周辺の塑性変形に寄与しない，また, ベー スプレートと基礎との回転離間後の再接触による衝撃力により柱 軸力は変動するが，鉛直方向加速度と同様，比較的高い振動数を 有し早期に減衰するため，柱脚周辺の塑性変形に寄与しない，

従って，鉛直方向については重力加速度のみを考慮すれば良く， 更に，上記の衝撃力も考慮しなくて良い．

3. 式 (10)により回転バネを有する柱の水平剛性を算出でき, 露出 柱脚付鋼構造物の第一層層剛性を簡便に評価できる．また，剛性 の観点から固定端と同等の応答を得るために必要な露出柱脚の弾 性回転剛性は，式(13) を満足することで得られる。そして, 試設 計ではあるが，柱と露出柱脚耐力比を 1.4 程度としても固定端で ある場合の応答に対応した結果は得られない ${ }^{23}$ ことを確認した.

従って, 露出柱脚を有する架構の地震時挙動を理解する上では, 柱と露出柱脚耐力比によらず半剛接合として扱うことが重要であ り，露出柱脚の弾性回転剛性を表現する要素を設置するべきであ ることを数理的に示した．但し一方で，柱と露出柱脚耐力比の変 化による弾性回転剛性の変動量は, 層剛性へ与える影響という観 点から小さいことも明らかである.

4. 側柱の梁の履歴形状や塑性変形量等から, 露出柱脚に現われる 柱軸力の変動による弾性回転剛性の変化が及ぼす影響は僅かで あった. 弾性回転剛性の変化が周辺架構へ与える影響が小さいこ とを示し,式(14)を視覚化した図 47 からも読み取ることができる.

5. ラーメン架構のアンカーボルトに作用寸るせん断力は, 側柱は 式 (9.b), 中柱は (9.a)により評価できる.

側柱のみではなく, 中柱のアンカーボルトにもせん断力は生じ る. その值は柱と露出柱脚耐力比が大きいほど減少し，一般的な 
ディテールのラーメン架構であれば, 圧縮側アンカーボルト群の

降伏せん断耐力を下回ることは明らかである.

6. 露出柱脚の履歴形状, 最大層間変形角を既知とできれば, 図 49 に示す手法により露出柱脚の最大回転角を評価することができる. 但し, 図 28 の挙動が現われると, 同手法の精度は極端に低下寸る. また, 式(16) を満足すれば, 最大層間変形角を露出柱脚の最大 回転角として安全側に定められる.

\section{謝辞}

本研究を執筆するにあたり, 東京工業大学名誉教授 笠井和彦先生, 広島工業大学名誉教授 高松隆夫先生, 長崎大学教授 故玉井宏章先 生よりご助言を賜りました。ここに記して，感謝の意を表します．

\section{参考文献}

1) Hiroshi Akiyama: Earthquake-Resistant Design for steel column-base, Gihodo, 1985. 3 (in Japanese)

2) Japanese Society of Steel Construction: Recommended provision pointer and commentary of exposed column-base with anchor-bolt for building structure, the first edition, 2009. 10 (in Japanese)

3) Masuda K.: Experimental studies on mechanical characteristics of the steel column bases: Part 1. Deformation behavior of column bases subjected to bending moment, Transactions of the Architectural Institute of Japan, Architectural Institute of Japan, Vol. 297, pp. 11-22, 1980. 11 (in Japanese)

4) Kutani K., Masuda K.: Experimental studies on ultimate strength of exposed type of steel column bases, Journal of Structural and Construction Engineering (Transactions of AIJ), No. 433, pp. 39-49, 1992.3 (in Japanese)

5) Kutani K., Masuda K.: Experimental studies on load carrying mechanism of exposed type of steel column bases, Journal of Structural and Construction Engineering (Transactions of AIJ), No. 440, pp. 113-124, 1992.10 (in Japanese)

6) Kawano A., Tanaka H., Ito M.: On the estimation of lateral stiffness of rahmen frame considered elastic rotation stiffness of exposed-type column base, Steel Construction Engineering (Transactions of JSSC), Vol. 10, No. 40, pp. 45-52, 2003. 12 (in Japanese)

7) Miyasaka H., Arai S., Uchiyama M., Yamada T., Hashimoto A.: Elasto-plastic behavior of structural elements consist in exposure fixed-type steel column-base, Journal of Structural and Construction Engineering (Transactions of AIJ), No. 550, pp. 167-174, 2001.12 (in Japanese)

8) Kadoya H., Kawaguchi J., Morino S.: Experimental study on elastic-plastic behavior and ultimate strength of exposure fixed-type steel column-base subjected to bending moment, Journal of Structural and Construction Engineering (Transactions of AIJ), No. 583, pp. 123-130, 2004.9 (in Japanese)

9) Yamada S., Akiyama H.: Influence of the rigidity of column-base on the ultimate earthquake resistance of multi-story steel moment frames, Journal of Structural and Construction Engineering (Transactions of AIJ), No. 496, pp. 113-118, 1997. 6 (in Japanese)

10) Kawano A., Matsui C.,: On the effect of restoring force characteristics of column-base on inelastic response behavior of weak beam steel frame under earthquake ground motion, Journal of Structural and Construction Engineering (Transactions of AIJ), No. 507, pp. 139-146, 1998.5 (in Japanese)

11)Hasegawa T.: Seismic response behavior of steel rigid frames having exposedtype column base, Journal of Structural Engineering, Vol. 46 B, pp. 657-665, 2000. 3 (in Japanese)

12) Sato K: A research on the a seismic behaviour of steel column base, PSSC, 1986. 13)Sato K: Structural performance and design for steel column base, The Kenchiku Gijutsu, No. 668, pp. 122-131, 2005.5 (in Japanese)

14) Kamagata S., Maeda S., Nishimura I,: Study on frame structure with column base earthquake motion proposal of hysteresis model for exposed steel column base, Summaries of Technical Papers of Annual Meeting, Architectural Institute of Japan, Structure-III, pp. 871-872, 1986.7 (in Japanese)

鎌形修一, 前田祥三, 西村功: 柱脚固定度を考慮した骨組み構造の地震時挙動 の研究 露出型柱脚の復元力モデルの提案, 日本建築学会大会学術講演梗概 集, 構造-III, pp. 871-872, 1986. 7

15) Kato B, Sato K., et al : Influence of hysteresis characteristics of column base on steel frames, part 1 : Response analysis of slip type model \& part 2 : Response analysis of elasto-plastic type model, Summaries of Technical Papers of Annual Meeting, Architectural Institute of Japan, Structure-III, pp. 867-870, 1986.7 (in Japanese)

加藤勉, 佐藤邦昭等 : 鋼構造露出柱脚の復元力特性が上部構造物に与える影 響について（その 1 : スリップ型モデルの応答解析），(その 2 : 完全弾塑性 型モデルの応答解析）, 日本建築学会大会学術講演梗概集, 構造 -III, pp. 867$870,1986.7$

16)Tamai H., Takamatsu T., Yamanishi T., Tada M., Matsukage T.: Collaborative seismic performance evaluation by use of distributed loading system - pseudo dynamic test on 5-story steel building with exposed column-base-, Journal of Structural and Construction Engineering (Transactions of AJJ), Vol. 73, No. 631, pp. 1665-1671, 2008.9 (in Japanese)

17)Tamai H., Takamatsu T., Yamanishi T., Shiraki T., Tada M.: Collaborative pseudo dynamic test on full scale non-slip-type exposed column-base, Proceedings of constructional steel (Transactions of JSSC), Vol. 14, pp. 269-276, 2006. 11 (in Japanese)

18)Tanaka H., Mitani I,. Shimamura Y., Itoh M.: Elasto-plastic behavior of steel frame with exposed type column base subjected to variable axial force, Steel Construction Engineering (Transactions of JSSC), Vol. 12, No. 45, pp. 171-184, 2005. 3 (in Japanese)

19) Yamada S., Suita K., Matsuoka Y., Shimada Y.: Elasto-plastic response and process leading to a collapse mechanism, dynamic collapse test of fullscale 4-story steel building (part 2), Journal of Structural and Construction Engineering (Transactions of AIJ), Vol. 74, No. 644, pp. 1851-1859, 2009. 10 (in Japanese)

20)Japan society of seismic isolation: Manual for Design and Construction of Passively-Controlled Buildings, the second edition, 2007. (in Japanese)

21)Yamanishi T., Kasai K., Tamai H., Takamatsu T.: Behaviour of frame \& columnbase for low-rise steel structure with exposed column-base, part 2 analysis results \& discussion, Proceedings of annual research meeting cugoku chapter (Transactions of AIJ), Vol. 37, pp. 201-204, 2014.3 (in Japanese)

22)Yamanishi T., Kasai K., Tamai H., Takamatsu T.: Rotational spring and seismic response of low-rise steel structure with exposed column-base and rotational spring, Proceedings of constructional steel (Transactions of JSSC), Vol. 22, pp. 354-361, 2014. 11 (in Japanese)

23)Architectural Institute of Japan, Recommendation for Design of Connections in Steel Structures, the third edition, 2012.3 (in Japanese)

付録 A ベースプレートと基礎との衝撃力の時刻歴

図 A-1 に, 解析 I 00.8 - E-L3 - G の 柱軸力 $N$, ベースプレート回転角 $\theta$ の 時刻歴を示寸. 中柱であるため, 柱軸 力は重力加速度に依存した軸力 $N_{D}=-$ $1,541 \mathrm{kN}$ が作用し, 梁のせん断力差に よる柱軸力変動はほぼ生じない.一方, ベースプレートと基礎との衝撃力によ り, $\theta=0$ 通過時に柱軸力の変動が生じ る. 但し, $\theta$ のピーク時にはほぼ収束 する, または変動幅は十分小さい.

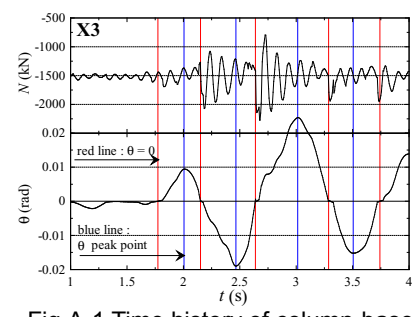

Fig.A-1 Time history of column-base (0.8 - E-L3 - G)
付録 B $\theta_{\mathrm{B}}$ 算定の各種式

先ず，各条件における分岐位置と第一層層間変形角 $r_{1}$ との関係式は，

${ }_{A} r_{1 s t-\mathrm{B}}={ }_{C} r_{1 s t-\mathrm{B}}=\frac{\theta_{B Y}}{K_{1 s t}}, \quad{ }_{B} r_{1 s t-\mathrm{B}}=\frac{\theta_{T Y}}{K_{1 s t}} \cdot\left(\frac{k_{T}}{k_{B}} \cdot \frac{\frac{1}{2} \cdot \frac{1}{k_{C}}+\frac{1}{k_{T}}}{\frac{1}{2} \cdot \frac{1}{k_{C}}+\frac{1}{k_{B}}}\right)$

${ }_{B} r_{2 n d-\mathrm{B}}=\theta_{B Y}+\frac{1}{12} \cdot \frac{1}{k_{C}} \cdot\left(4 M_{B Y}-2 M_{T Y}\right), \quad{ }_{C} r_{2 n d-\mathrm{B}}=\theta_{T Y}+\frac{1}{12} \cdot \frac{1}{k_{C}} \cdot\left(4 M_{T Y}-2 M_{B Y}\right) \quad$ (B-1.c, d)

となる, 次に, 各領域の層間変形角と回転角との関係は以下で表現できる。

$$
\begin{aligned}
& { }_{A} \theta_{B-2 n d}=\theta_{B Y}+r-{ }_{A} r_{1 s t-B},{ }_{B} \theta_{B-2 n d}=\frac{M_{T Y}}{k_{B}} \cdot \frac{\frac{1}{2} \cdot \frac{1}{\frac{1}{2} \cdot \frac{1}{k_{C}}+\frac{1}{k_{T}}+\frac{1}{k_{B}}}+{ }_{B} K_{2 n d} \cdot\left(r-{ }_{B} r_{1 s t-B}\right)}{{ }_{C} \theta_{B-2 n d}}=\theta_{B Y}+{ }_{C} K_{2 n d} \cdot\left(r-{ }_{C} r_{1 s t-B}\right) \\
& { }_{B} \theta_{B-3 r d}=\theta_{B Y}+r-{ }_{B} r_{2 n d-B} \\
& { }_{C} \theta_{B-3 r d}=\theta_{B Y}+{ }_{C} K_{2 n d} \cdot\left({ }_{B} r_{2 n d-B}-{ }_{B} r_{1 s t-B}\right)+\left(r-{ }_{B} r_{2 n d-B}\right) \\
& { }_{D} \theta_{B-\max }=\frac{{ }_{C} M_{P C}}{k_{B}}
\end{aligned}
$$


DEFORMATION BEHAVIOR \& WORKING STRESS OF COLUMN-BASE FOR STEEL STRUCTURE WITH EXPOSED COLUMN-BASE ON GROUND MOTION

- Time history response analysis for 4-story 2-dimension moment resist frame -

\section{Teruaki YAMANISHI*1}

${ }^{1}$ Assoc. Prof., Faculty of Eng., Hiroshima Institute of Technology, Dr.Eng.

Exposed column-base had double flag type restoring force characteristics, and it strength, rotational rigidity \& hysteresis were affected by the column axial force. That characteristics understand obtain from partial frame experiment. Moreover, the influence of its characteristics on steel structure seismic response examined by time history analysis of steel structure with rotational spring, that rotational spring had double flag type restoring force characteristics.

However, partial frame experiment was no agreement boundary condition of column-base in structure on ground motion, and rotational spring was no agreement influence of axial force. Therefore, seismic response \& working stress of exposed column-base with steel structure included many uncertainty about building structural design.

The author discussed exposed column-base behavior and structure response on ground motion, that uses seismic response analysis results obtain from low-rise steel structure with model that can reproduce the column-base behavior.

In this paper, elucidate and estimate for exposed column-base mechanism and effective working stress, frame response. The following conclusions were drawn.

1. Exposed column-base around plastic deformation are affected by variable axial force caused shear force gap of beams of layer direction. As a results, yield element changes around of column-base in column-base strength ratio range from 0.8 to 1.2.

2. Exposed column-base around plastic deformation are unaffected by up-down acceleration of earthquake. On the other hand, gravity acceleration are very important consideration in its understand.

3. Exposed column-base had semi-rigid connect behavi , if its strength over the column full-plastic strength.

4. A change in rotational rigidity change in variable axial force were few effect to frame response.

5. Shear force of anchor-bolts and shear-key occurs external column and internal column. And its values approximately equal yield shear strength of single anchor-bolt.

6. Maximum of base plate rotation evaluated method shown, obtain from maximum story drift angle and mechanics model of column with rotational spring. 